\title{
A faunistic contribution to the butterfly fauna of Oman (Lepidoptera: Diurna)
}

\author{
Peter Schmidt ${ }^{1}$, SÁndor Jenő Simonyi ${ }^{2}$, Levente Ábrahám ${ }^{1}$, \\ SZABOLCS SÁFIÁN ${ }^{3} \&$ SÁNDOR ILNICZKY ${ }^{4}$ \\ ${ }^{1}$ Rippl-Rónai Museum Kaposvár Fő str. 10., Hungary, \\ e-mail: peter.schmidt.smmi@gmail.com and labraham@smmi.hu \\ ${ }^{2}$ H-1031 Budapest, Sóvári str. 30. fsz. 1., Hungary, e-mail: simonyisandorjeno@gmail.com \\ ${ }^{3}$ Institute of Silviculture and Forest Protection, University of Sopron, H-9400 Sopron \\ Bajcsy-Zsilinszky str. 4., Hungary, e-mail: szsafian@gmail.com \\ ${ }^{4}$ H-1173 Budapest, Szenczi Molnár Albert str. 35., Hungary, e-mail: ilniczkysandor@gmail.com
}

\begin{abstract}
Schmidt, P., Simonyi, S. J., Ábrahám, L., SÁfí́n, Sz. \& Ilniczky, S.: A faunistic contribution to the butterfly fauna of Oman (Lepidoptera: Diurna).

Abstract: During five entomological field expeditions between 2008 and 2019, butterfly speciemens were collected in Oman, and a total of 492 specimens of 46 species were documented. Faunistic and distribution data for each species is presented, along a short overview of the physical geography of Oman and biogeographical notes of the butterfly fauna. With 30 figures.
\end{abstract}

Keywords: butterfly, faunistic, distribution, Oman.

\section{Introduction}

The Sultanate of Oman is located at the southeastern coast of the Arabian Penninsula. The country's landscape is divided into two major ecoregions, (1) Temperate grasslands, savannas, and shrublands, (2) Deserts and xeric shrublands. The former includes the higher regions of the rocky, $650 \mathrm{~km}$ long Al Hajar Mountain range from the tip of the Musandam peninsula to Ra's Al Had. The rest of the country falls in the second group, but is not homogeneous and further subdivided into five subregions. The Gulf of Oman desert and the semi-desert subregion stretches $270 \mathrm{~km}$ long in the Batinah Plain, an inland strip running along the southwest of the Al Hajar Mountains. The Arabian Desert and East Saharo-Arabian xeric shrublands are part of the Arabian Desert that dominates the peninsula and also extends to Oman. The Arabian Peninsula coastal fog desert, which is a narrow coastal stretch of land along the southeastern and southwestern coast of the peninsula. Perhaps the most special area is found in Southwest Oman. The Southwestern Arabian foothills savannah in the Qara Mountain Range (or the Dhofar Mountains) is the most unique due to permanent influence of subtropical monsoon climate (BURGESS et al. 2004).

Studies of the butterfly fauna of the Arabian Peninsula date back to the first half of the 19th century (KLUG 1829-32). However, the research of Lepidoptera fauna in Oman intensified only much later in the second half of the 20th century. The area's first cata- 
logue of butterfly fauna was compiled in the 1980s, which already included an insight of the zoogeography of Oman's butterflies (LARSEN \& LARSEN 1980, LARSEN 1984b).

Further publications on butterflies were presenting results of research on the biology, ecology or occurrences of various species (COCK 2009, FeUlner 2007, GILlet 1995, GILlet \& NASSER 2005, NASSER 2005, Fric et al. 2019), also reporting checklists recorded over short faunistic surveys (POLAK \& VEROVNIK 1998, 2009). Most recently CowAN \& CowAN (2019) composed the checklist of the butterfly fauna of Dhofar based on LARSEN (1983), listing 63 species from the area.

This paper serves as a further faunistic work that provides accurate biotic information on the butterfly species collected on five field trips between 2005 and 2019, including geo-referenced distribution records and an up to date taxonomic review.

\section{Material and methods}

Between 2008 and 2019, five insect collecting expeditions were organized by Hungarian entomologists in Oman. The members of the expeditions mainly collected beetles, butterflies and moths, lacewings and other group of insects. The voucher specimens of butterflies are deposited in the private reference collections of Sándor Jenö Simonyi and Sándor Ilniczky (Budapest) and in the scientific collection of the RipplRónai Museum (Kaposvár). Butterflies were sampled in conventional methods using a hand-held butterfly net.

Sampling dates and collectors:

15-30. 04. 2008 - S. Ilniczky, S. J. Simonyi

10-16. 10. 2009 - S. Ilniczky, S. J. Simonyi

02-17. 07. 2010 - S. Ilniczky, S. J. Simonyi

27.10.-04.11. 2018 - L. Ábrahám, S. Ilniczky, S. J. Simonyi

25.04.-08. 05. 2019 - L. Ábrahám, S. Ilniczky, G. Körtési

The two main collecting sites of butterflies in Oman were the Al Hajar Mountain range in the north and the Qara Mountain range in the southwest. In all other sites, due to the species-poor fauna, data collection was more occasional.

The higher taxonomy and generic order follow WiLLIAMs (2015). The majority of distribution data and foodplant records are retrieved from LARSEN \& LARSEN (1980), LARSEN $(1991,2005)$ and WiLLIAMS (2019).

\section{Results and discussion}

Papilionidae Latreille, 1802

Papilionini Latreille, [1802]

Papilio demodocus (Esper, 1798)

Material examined: 12 exx. / OMAN, Gov. Dhofar / 7 km W of Mirbat / N1701.578' E54³9.322' / $31 \mathrm{~m}$ seashore, sand dunes / 30. 04.2019 / leg. L. Ábrahám, S. Ilniczky, G. Körtési. 


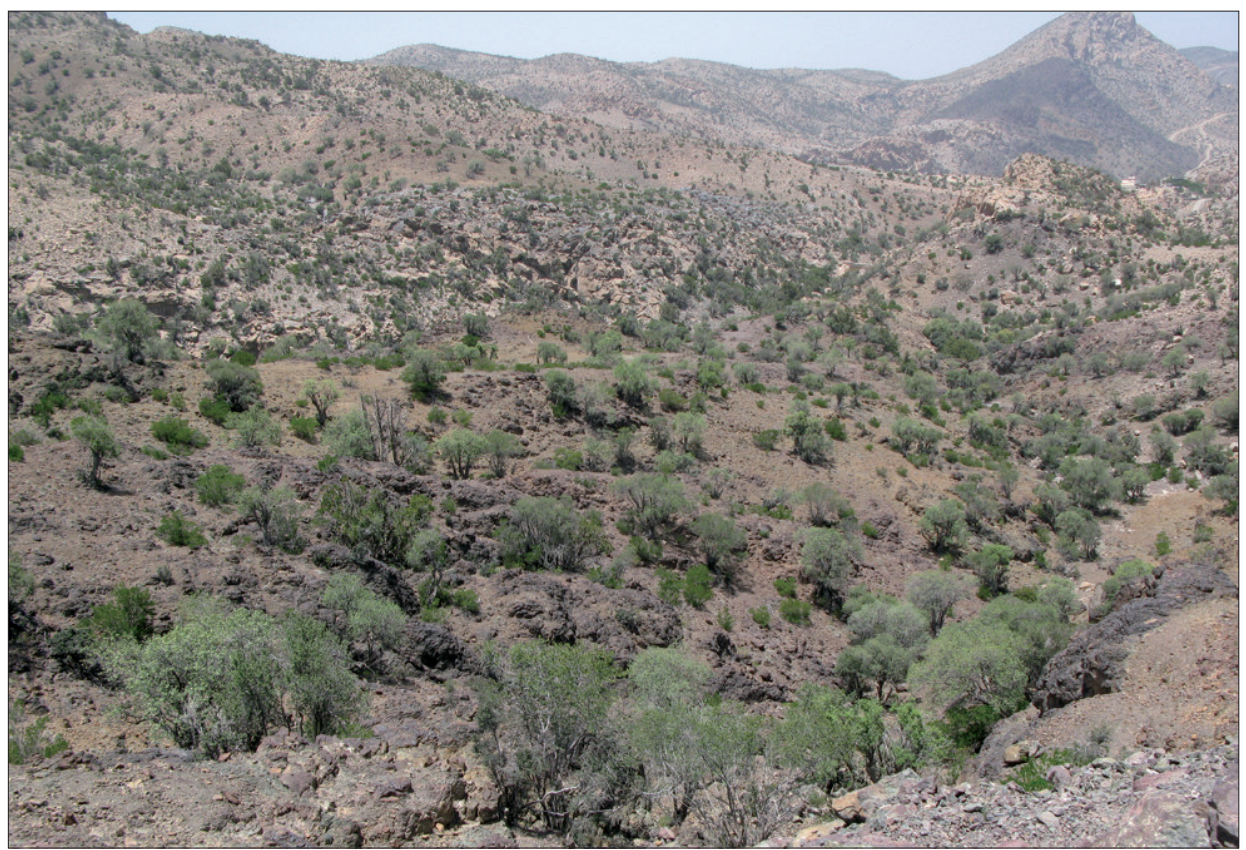

Fig. 1: Temperate grasslands, savannas, and shrublands in the Al Hajar Mountain range, shrublands in the Jabal al Akhdar (Green Mountain) near Misfah

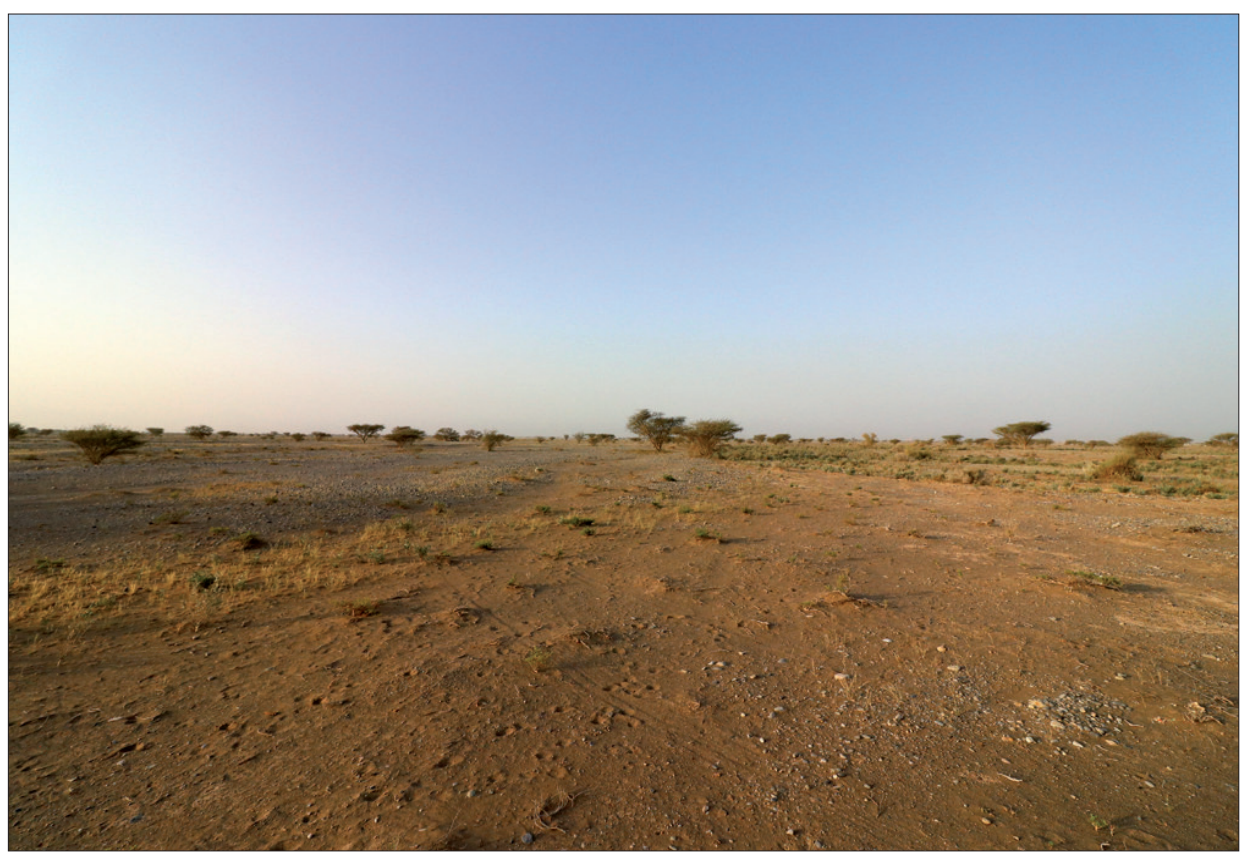

Fig. 2: Desert and the semi-desert ecoregion in the Batinah Plain with Acacia trees and scrubs 


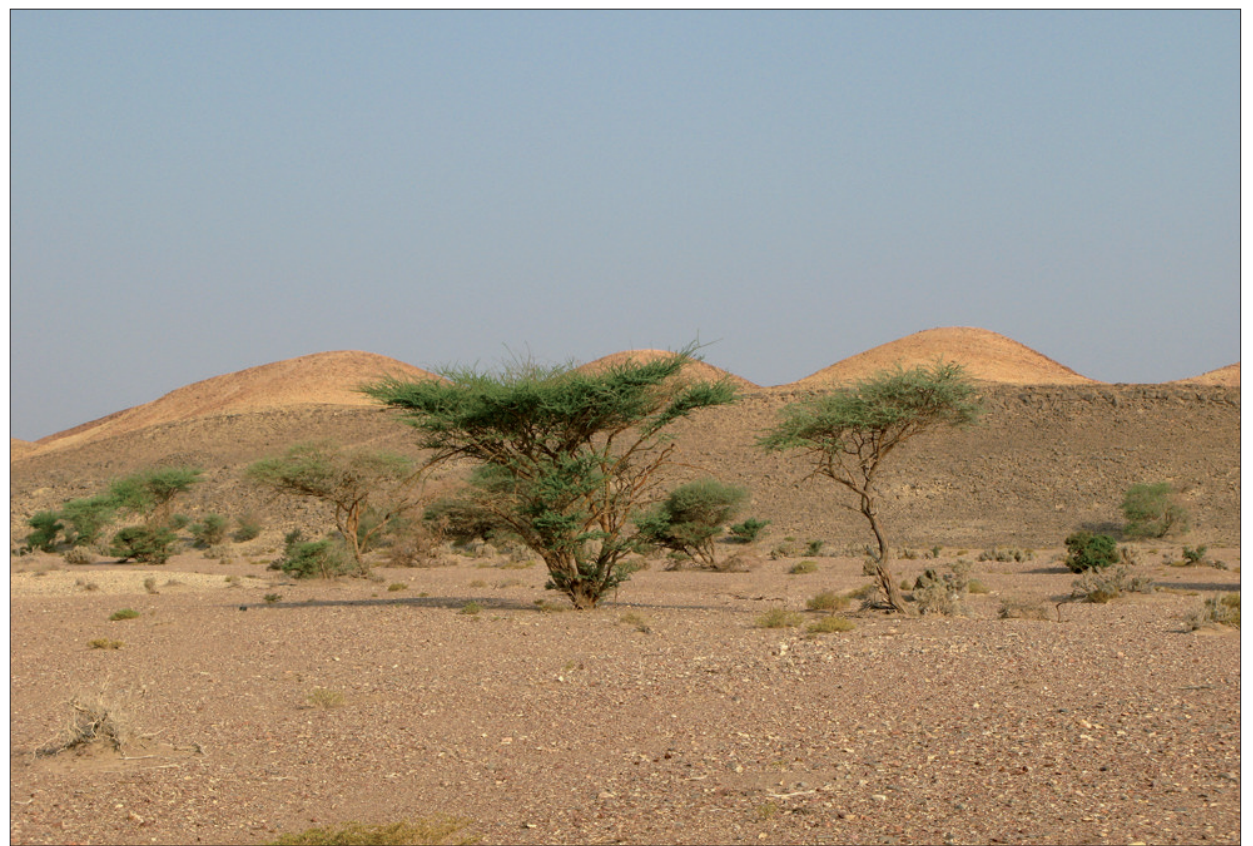

Fig. 3: The Al Hajar Al Gharbi montane woodlands ecoregion, the vegetation dominated with Acacia trees

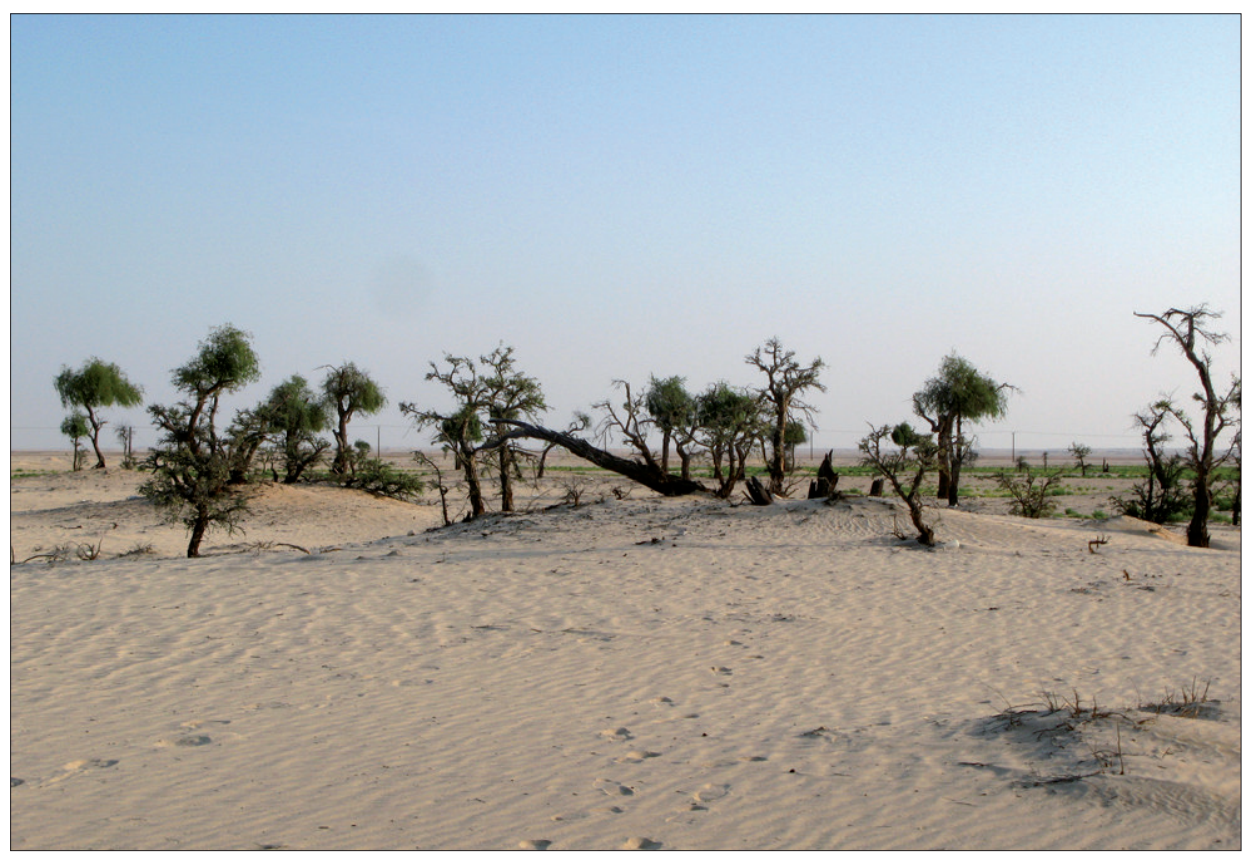

Fig. 4: The Arabian Desert and East Saharo-Arabian xeric shrublands ecoregion, sand desert with Prosopis trees near Mughshin. 


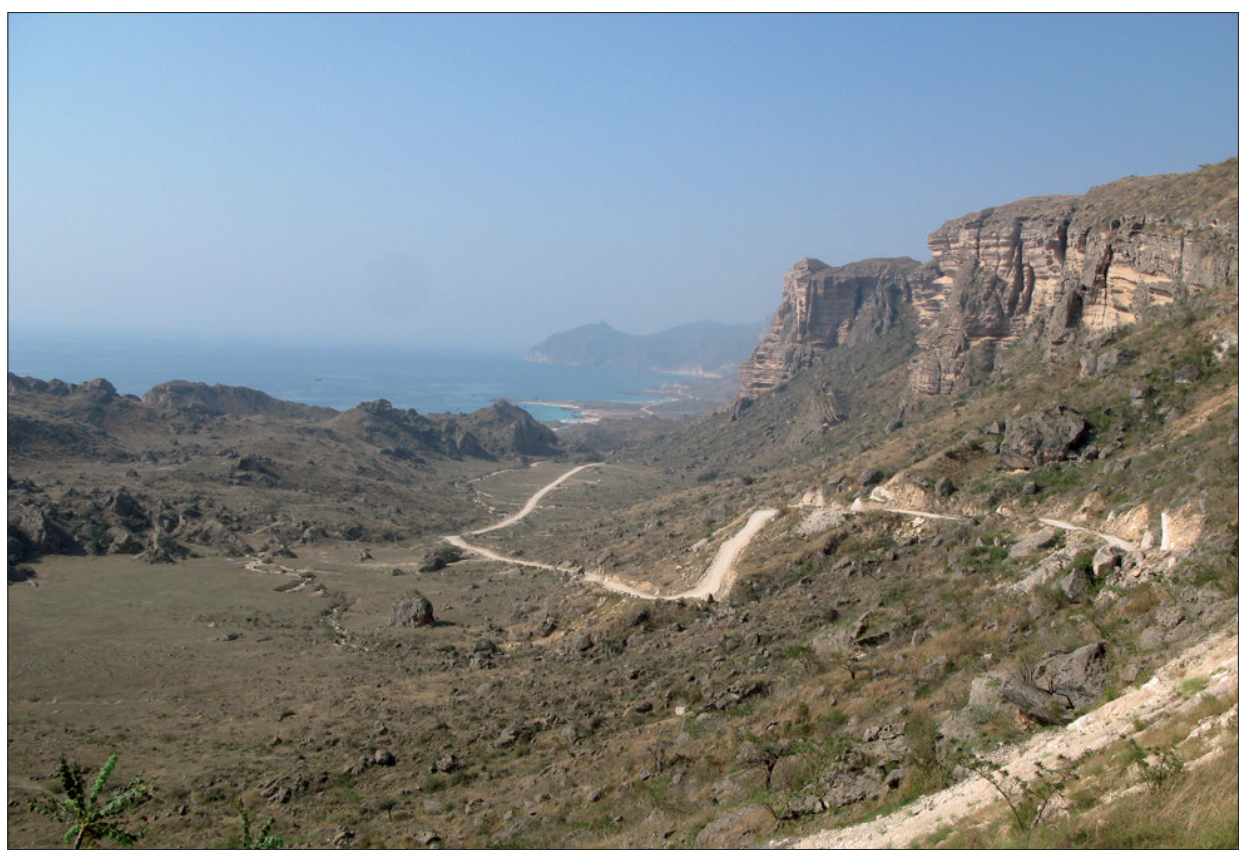

Fig. 5: The Southwestern Arabian foothills savanna ecoregion in the Qara Mountain Range near Mughsayl

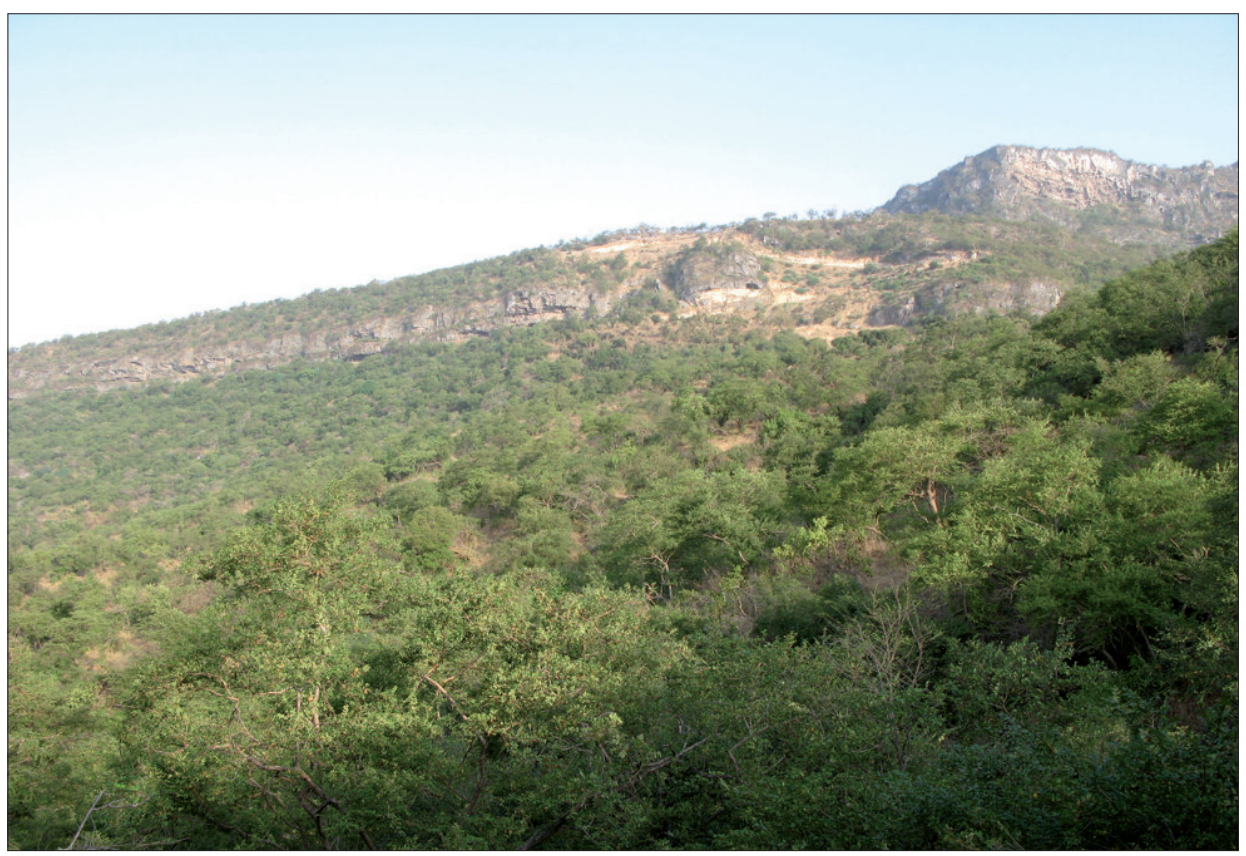

Fig. 6: The Qara Mountain Range dry forested area near Mugurah 


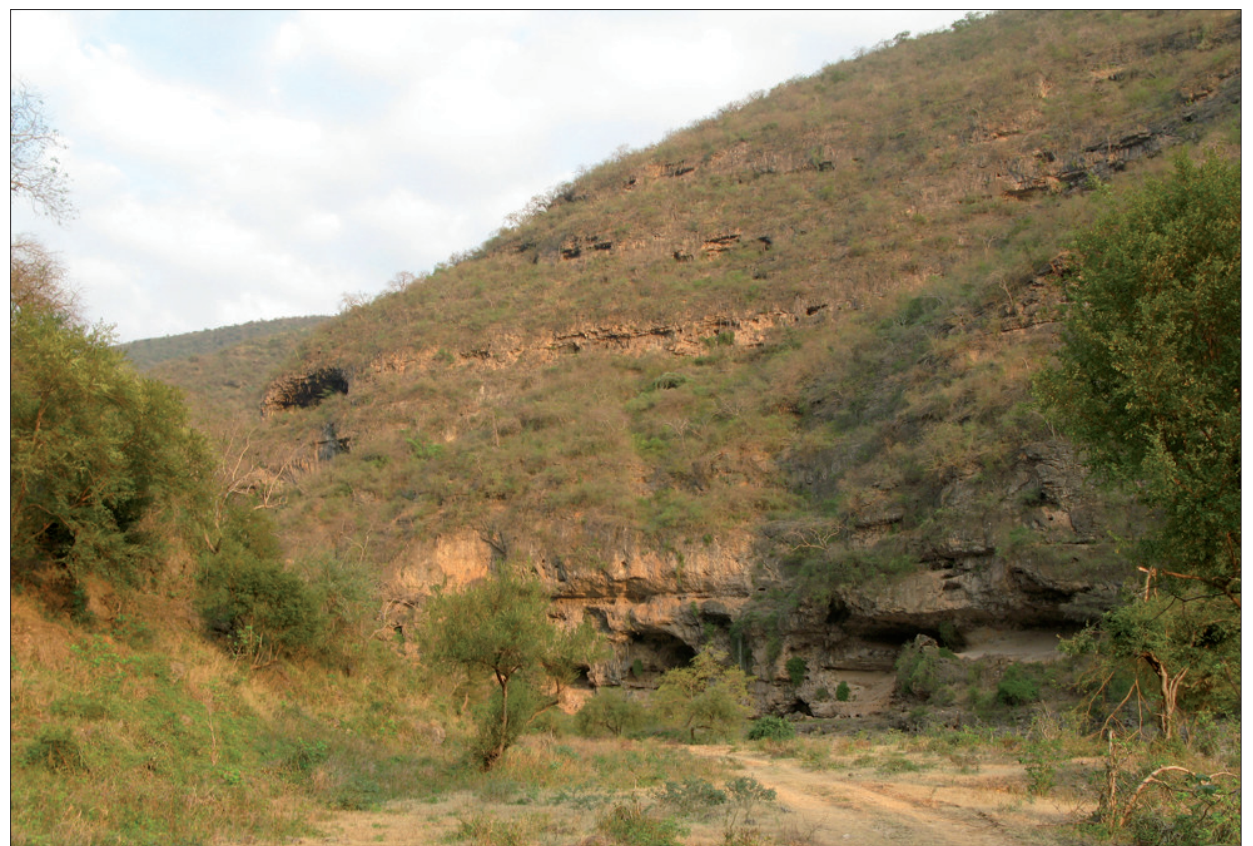

Fig. 7: The Qara Mountain Range wadi near Rakhyuth

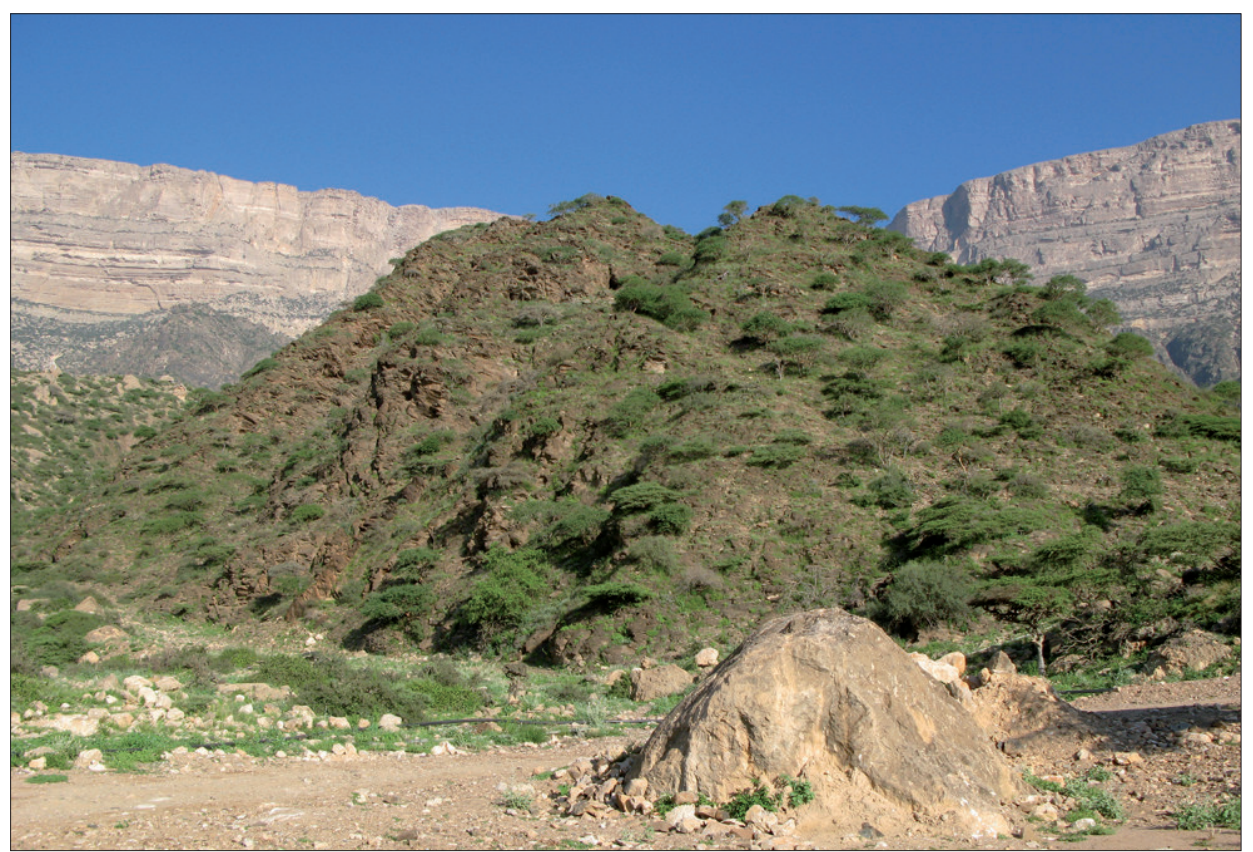

Fig. 8: The Qara Mountain Range, the Jabal Samhan foothill savannah with Boscia trees 
Distribution: It is an Afrotropical species, contrary to the closely related $P$. demoleus (Linnaeus, 1758), which was also recorded in Oman. P. demodocus is distributed in the whole sub-Saharan Africa, including the majority of Atlantic and Indian Ocean Islands (WiLliams 2019). It is found also in the coastal zone of the Arabian Peninsula. In Oman, it occurs only in Dhofar, where it is locally common.

Remarks: Originally, both $P$. demodocus and $P$. demoleus were woodland butterflies where they utilized indigenous species of Rutaceae, but both adopted various cultivated Citrus as a larval food plants. As potential pest species, they occasionally cause agricultural damages (LARSEN \& LARSEN 1980). P. demodocus was reported feeding on Haplophyllum tuberculatum (Rutaceae) in its natural habitats in Dhofar (LARSEN 1982).

Papilio demoleus (Linnaeus, 1758)

Material examined: 2 exx. / OMAN, Reg. Al Batinah South, Ar Rustaq, / N2324.903' E57²5.517' 339 m, oasis,/ 16.04.2008 /leg. S. Ilniczky, S. J. Simonyi.

Distribution: The Lime Swallowtail is a well-known Oriental-Indo-Australian papilionid butterfly, that had three largely disjunct distribution areas from Arabia to Australia, but from the 1950's it extended its range widely to the whole tropical and subtropical parts of Asia and the Indonesian territories, as it became a renowned economic pest on Citrus and also an invasive species (LARSEN \& LARSEN 1980). In Oman, it can be found in Northern Oman. Currently, the range of $P$. demoleus does not overlap with that of $P$. demodocus.

Remarks: It was introduced to the New World in 2004 (Hispaniola, Dominican Republic (Guerrero 2004)), and was found in South-Portugal in 2012, for the first time on the mainland of Europe (Morgun \& WiEMERs 2012). The larvae also feed on Citrus on agricultural areas, different Rutaceae and Fabaceae (Australia) in natural circumstances. This species can be found in forests but is normally associated with more open habitats ranging from semi-desert to Acacia scrub, savannah and woodland mosaics, parks and gardens (GUERRERo 2004).

Hesperiidae Latreille, 1809

Coeliadinae Evans, 1937

Pyrrhiades anchises jucunda (Butler, 1881) (Fig. 13-14)

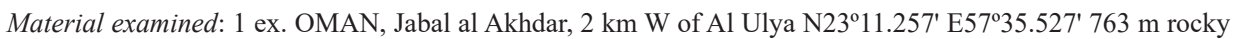
wadi with sparse bushy, 16.04.2008 leg. S. Ilniczky, S. J. Simonyi; 2 exx. OMAN, Jabal al Akhdar, Balad Seet, $\mathrm{N} 23^{\circ} 11.794^{\prime}$ E5 $7^{\circ} 13.426^{\prime} 914 \mathrm{~m}$, gorge below the willage with spring and oasis, 17.04.2008 leg. S. Ilniczky, S. J. Simonyi; 1 ex. OMAN, Gov. Dhofar, Jabal al Qamar, seashore below Mugurah, N16º $45.768^{\prime}$ E5330.661' 16 m, 05.10.2009. leg. S. Ilniczky, S. J. Simonyi; 1 ex. OMAN, Gov. Dhofar, Jabal al Qara, W of Al Mughsayl, N1651.243' E5343.189' 496 m 07.07.2010 leg. S. Ilniczky, S. J. Simonyi; 2 exx. OMAN, Gov. Dhofar, Jabal al Qara, W of Al Mughsayl, N16²51.243' E53²43.189' 496 m, 06.07.2010 leg. Ilniczky, S. J. Simonyi; 1 ex. OMAN, Gov. Dhofar, Jabal al Qamar, seashore below Mugurah, N16²45.930' E53³0.811' 42 m, 09.07.2010 leg. S. Ilniczky, S. J. Simonyi; 30 exx. / OMAN, Reg. Al Dakhiliyah / Misfah, Jabal Shams / N23 ${ }^{\circ} 14.154^{\prime}$ E5708.987' / 1400 m rocky wadi / 05.05.2019 / leg. L. Ábrahám, S. Ilniczky, G. Körtési; 9 exx. / OMAN, Reg. Al Batinah South / Balad Seet / N23⒒794' E57²3.426' / 914 m oasis, spring / 06.05.2019 / leg. L. Ábrahám, S. Ilniczky, G. Körtési.

Taxonomic note: With its Malagasy relative Pyrrhiades pansa (Hewitson, [1867]), P. anchises for a long time was included in the genus Coeliades Hübner, [1818], but was moved to Pyrrhiades Lindsey \& Miller, 1965 by CHIBA (2009) in his revision of the 
Coeliadinae subfamily, based on morphological characters, including antennal length, wing venation and male genitalia.

Distribution: P. anchises anchises (Gerstaecker, 1871) can be found sporadically in Southern and Eastern Africa, also reported from Yemen on the Arabian Peninsula. The population of this characteristic butterfly on the Island of Socotra differs from the African ones and is considered as a distinct, endemic subspecies jucunda Butler, 1881. The same subspecies was reported also from southern Oman (LARSEN \& LARSEN 1980, LARSEN 1984), however, according to Steve Collins (pers.comm.) these more jucundalooking specimens could be a result of historic interbreeding between the Southern Arabian $P$. anchises anchises and specimens of $P$. anchises jucunda occasionally blown over from Socotra, where the latter is generally very common.

Remarks: Currently, the taxon is treated as endemic subspecies of Oman and Socotra. It flies extremely fast, similar to other skippers, in relatively low altitude of the mountainous wadis of Northern Oman. In the Arabian Peninsula, the larvae feed on Acridocarpus orientalis. Specimens could be most easily observed around the blooming food plants, where they spend hours feeding on nectar, particularly at dusk and at dawn. During the day, male specimens could be seen mud-puddling in wadis, along small creeks. According to the sampled specimens, the imagoes are on the wing between April and July.

\section{Pyrginae Burmeister, 1878 \\ Sarangesa phidyle (Walker, 1870)}

Material examined: 1 ex. / OMAN, Gov. Dhofar / 3 km W of Rakhyuth / N16 ${ }^{\circ} 45.225^{\prime}$ E532 $23.905^{\prime} / 36$ m wadi / 31.10.2018 / leg. L. Ábrahám, S. Ilniczky; 1 ex. / OMAN, Gov. Dhofar / 20 km W of Al Mughsayl / $\mathrm{N} 16^{\circ} 50.051^{\prime} \mathrm{E} 53^{\circ} 42,552^{\prime} / 34 \mathrm{~m}$ seashore, dry rocky vegetation / 01.11.2018 / leg. L. Ábrahám, S. Ilniczky.

Distribution: The Small Elfin is distributed in most parts of southern and southwestern Africa, in northwestern Africa, and it is also present in drier savannah habitats across sub-Saharan Africa. It reaches the southern part of the Arabian Peninsula (Oman, Yemen) as well.

Remarks: It is obviously the most widely distributed species of the Sarangesa genus, also the only that occurs in Arabia. In Oman, it is widespread but quite local in Dhofar, it was found only in the narrow, coastal zone. The larvae feed on different Acanthaceae species (LARSEN \& LARSEN 1980). According to the samples collected, the imagos fly during autumn (October-November).

Nymphalidae Rafinesque 1815

Danainae Boisduval, 1833

Danaus chrysippus (Linnaeus, 1758) (Figs. 15-16)

Material examined: 1 ex. / OMAN, Reg. Al Batinah South, Ar Rustaq / N2324.003' E57²5.517' 339 m, oasis/ 16.04.2008 / leg. S. Ilniczky, S. J. Simonyi; 2 exx. OMAN, Gov. Dhofar, Jabal al Qamar, below Mugurah, N16²5.768' E53³0.661' seashore, 16 m, 15-16.10.2009. leg. S. Ilniczky, S. J. Simonyi; 1 ex. OMAN, Jabal

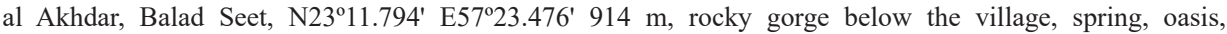
17.04.2009 leg. S. Ilniczky, S. J. Simonyi; 18 exx. / OMAN, Gov. Dhofar, / 2 km E of Rakhyuth / N16 $44.968^{\prime}$ E53²6.256 / 22 m, seashore / 31.10.2018 / leg. L. Ábrahám, S. Ilniczky; 3 exx. / OMAN, Gov. Dhofar / 7 km

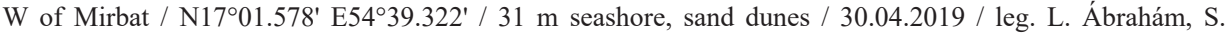
Ilniczky, G. Körtési; 14 exx. / OMAN, Reg. Al Batinah South / Balad Seet / N23¹1.794' E57²3.426' / 914 m oasis, spring / 06.05.2019 / leg. L. Ábrahám, S. Ilniczky, G. Körtési. 


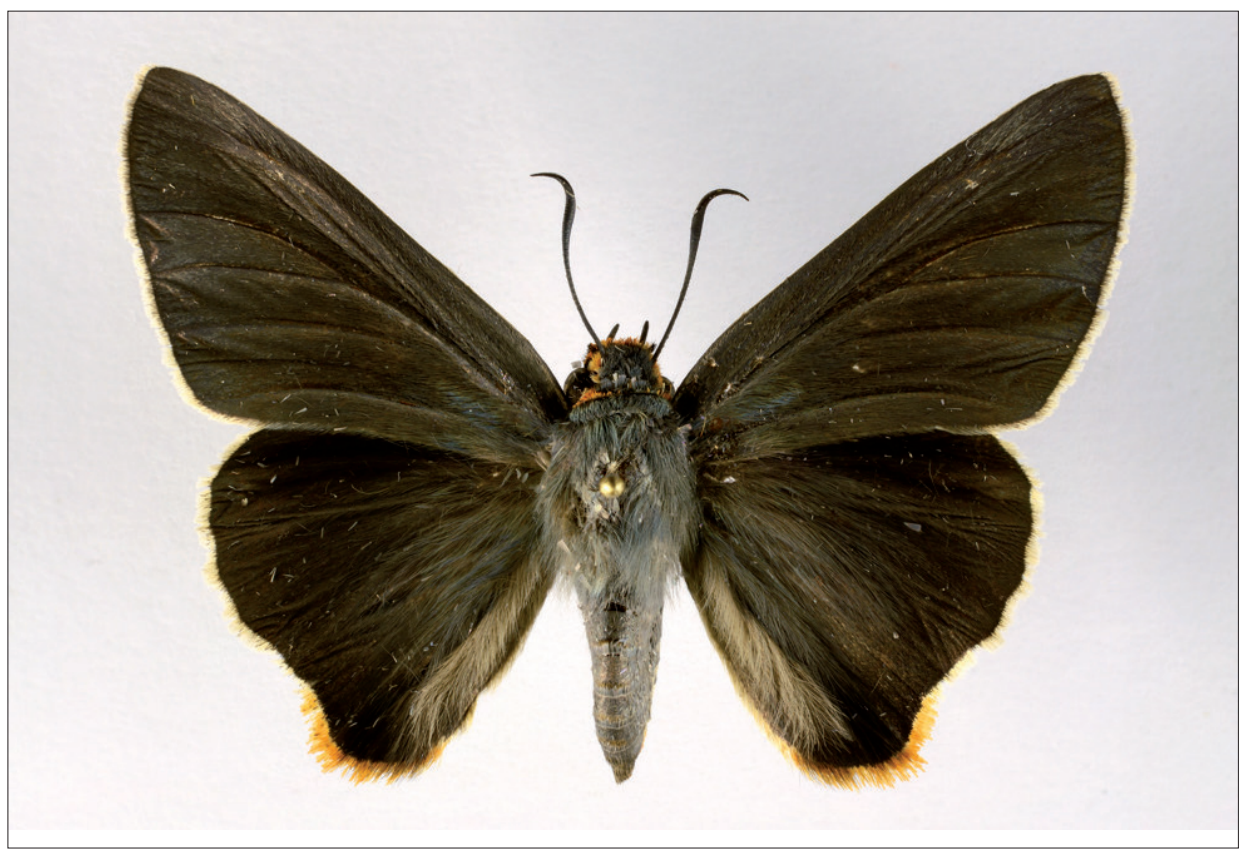

Fig. 13: Pyrrhiades anchises jucunda (Butler, 1881) male upper side

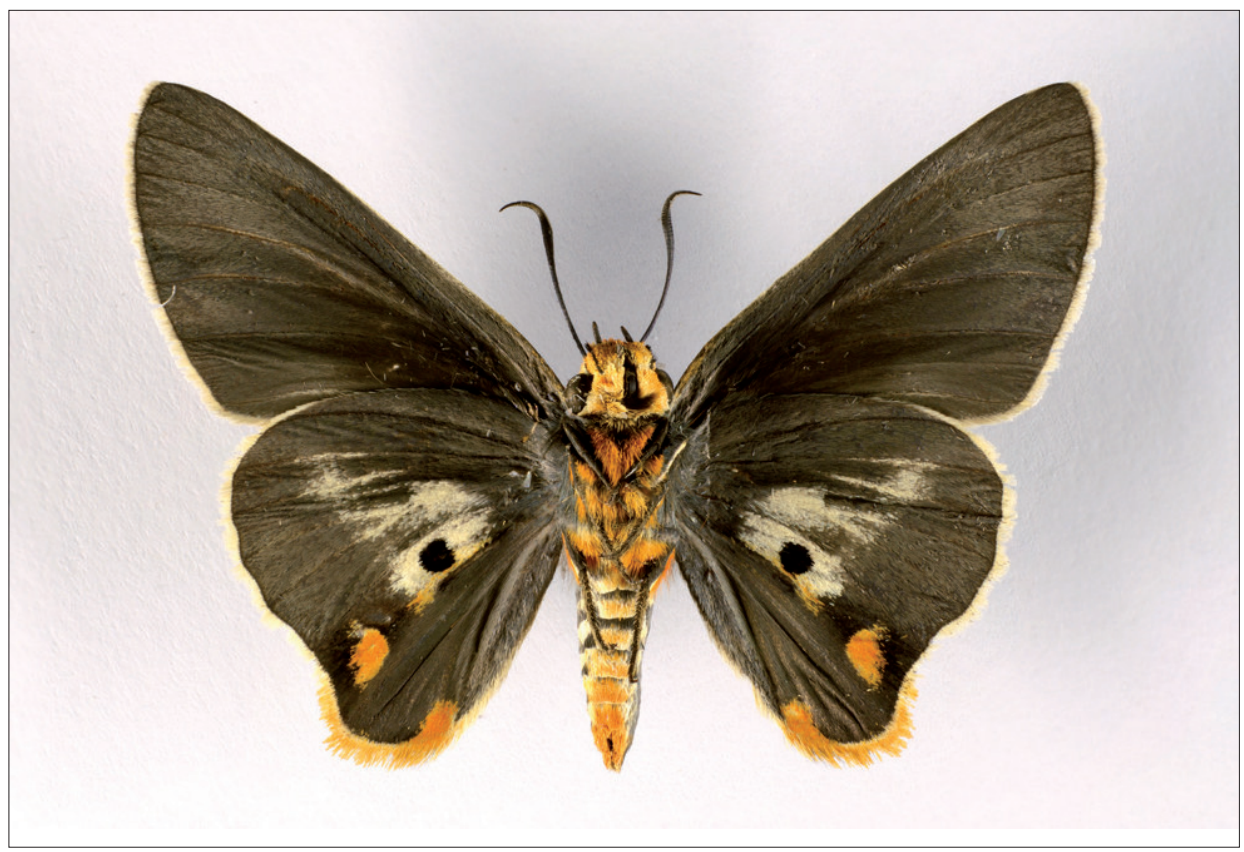

Fig. 14: Pyrrhiades anchises jucunda (Butler, 1881) male under side 


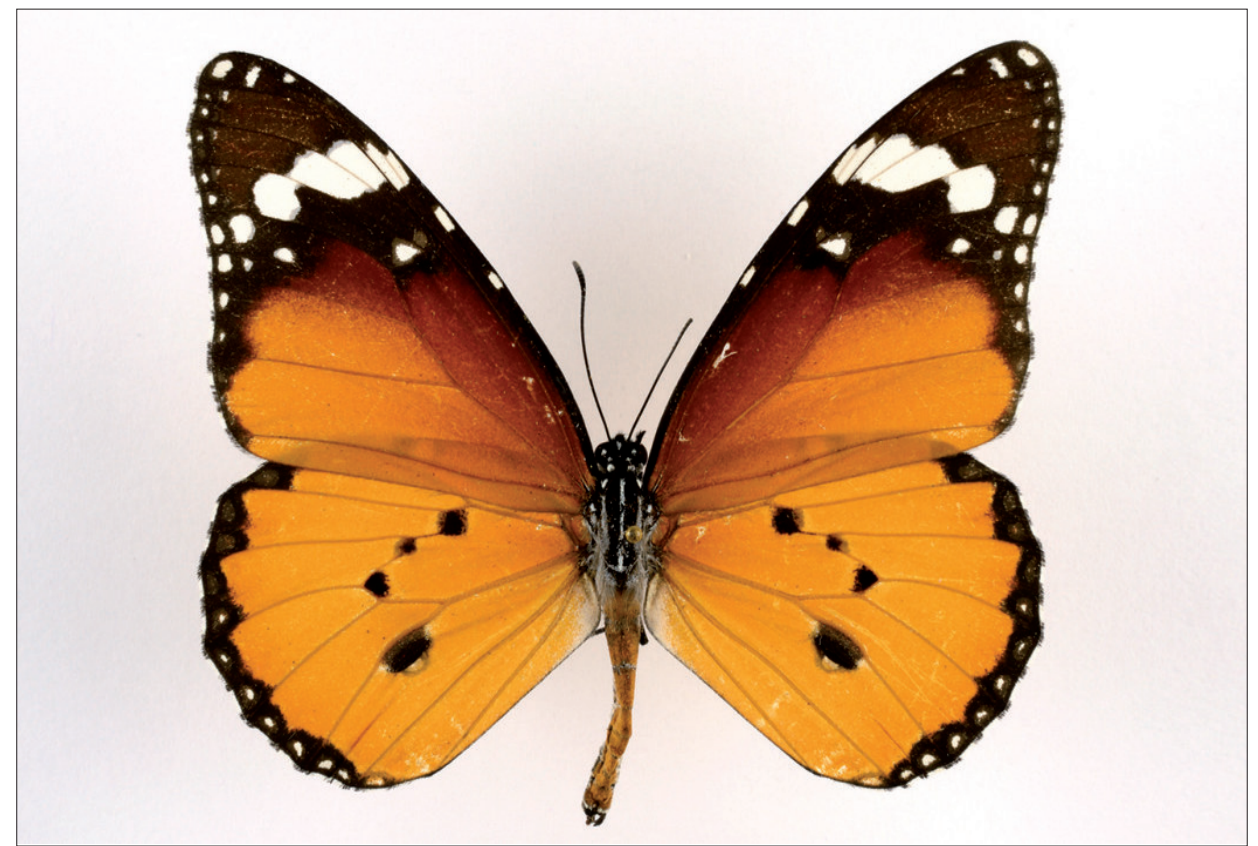

Fig. 15: Danaus chrysippus (Linnaeus, 1758) male upper side

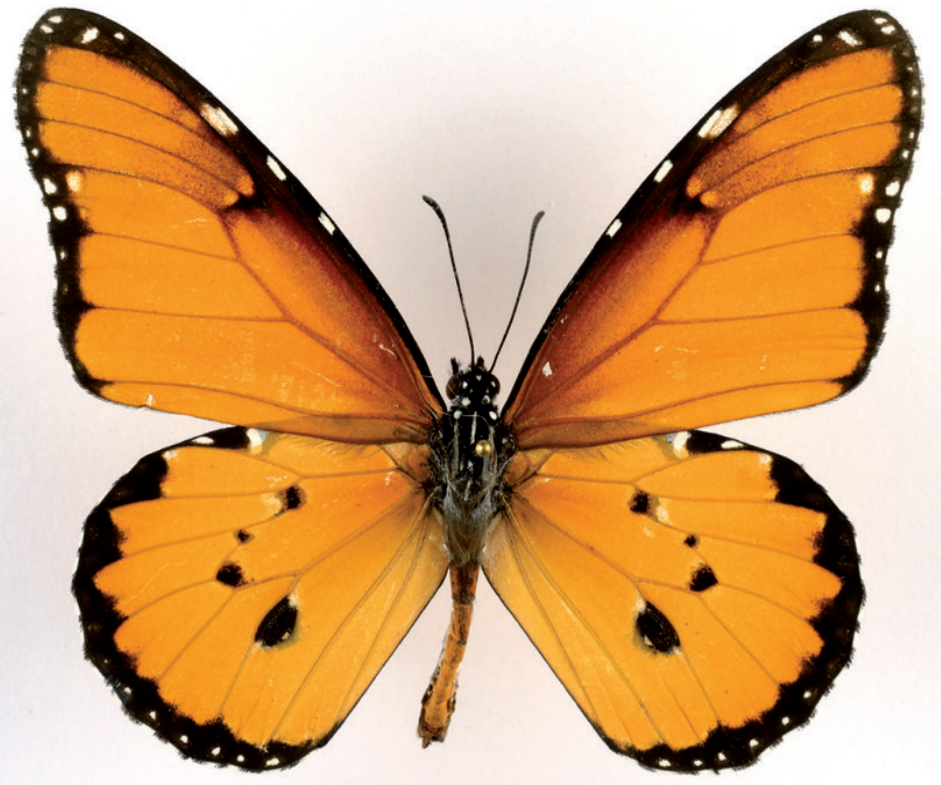

Fig. 16: Danaus chrysippus (Linnaeus, 1758) f. dorippus male upper side 
Distribution: The Plain Tiger or African Monarch butterfly has an enormous distribution range, that covers the Canary Islands, most of the coastal area of the Mediterranean Sea (excluding the Adriatic coastline), most of Africa, certain parts of Arabia, the Middle East, the subtropical and tropical parts of Asia and also Australia.

Remarks: It is a good flier and migrant species, but in Arabia this phenomenon is insignificant. Rather common in Oman, especially around oases. The larval host plants are various Asclepiadaceae, mostly Calotropis procera in Oman (LARSEN \& LARSEN 1980). The form dorippus is sometimes considered a different species (SMITH et al, 2005). It occurs in Oman as well, 16 of the 38 specimens are the representative of this form.

Hypolimnas misippus (Linnaeus, 1764)

Material examined: 1 ex. OMAN, Gov. Dhofar, W of Al Mughsayl, N16 $51.824^{\prime}$, E53²43.217' 76 m, rocky gorge across the main road, 13.10.2009 leg. S. Ilniczky, S. J. Simonyi; 1 ex. OMAN, Gov. Dhofar $/ 2$ km E of Rakhyuth / N16²4.968' E53²6.256' / 22 m, seashore / 31.10.2018 / leg. L. Ábrahám, S. Ilniczky.

Distribution: It is a widespread species, that is distributed in huge territories of tropical and subtropical Africa, Asia and Central-America (LARSEN 2005, Williams 2019).

Remarks: Although a widespread species, it is not a common butterfly in Oman. The males are unmistakable but the appearance of the females is completely different. As one of the well-known examples of female-limited Batesian mimetic polymorphism, where the different forms of non-toxic female $H$. misippus closely resemble the various forms of the poisonous Danaus chrysippus (eg. Smith 1973, Gordon 1987, KunTe 2009).

\section{Satyrinae Boisduval, 1833 \\ Hipparchia parisatis (Kollar, 1849) (Figs. 17-18)}

Material examined: 1 ex. OMAN, Jabal al Akhdar, Balad Seet, N23ำ11.794' E57²3.476' 914 m, rocky gorge below the village, spring, oasis, 04.17.2009 leg. S. Ilniczky, S. J. Simonyi; 1 ex. / OMAN, Reg. Al Dakhiliyah / Jabal Shams / N23ำ15.339' E57²13.092' / 2138 m rocky and bushy vegetation / 05.06.2019 / leg. L. Ábrahám, S. Ilniczky, G. Körtési; 1 ex. / OMAN, Reg. Al Batinah South / Balad Seet / N23¹1.794' E57²3.426' 914 m oasis, spring / 06.05.2019 / leg. L. Ábrahám, S. Ilniczky, G. Körtési.

Distribution: It is distributed from Eastern Turkey, through most of the Middle East to Northwestern India and Western China. H. parisatis has an isolated population in the mountainous areas of Northern Oman.

Remarks: Although it has a limited range in Arabia, the species is relatively common on the peninsula. In contrary to most of Omani butterflies, it is single-brooded with the imagos flying in May and June, then, after aestivation, they re-appear also in the autumn (LARSEN \& LARSEN 1980). The larval host plants could be different Poaceae.

Ypthima asterope (Klug, 1832)

\footnotetext{
Material examined: 1 ex. OMAN, Jabal al Akhdar, $2 \mathrm{~km}$ W of Al Ulya, N23 ${ }^{\circ} 11.287^{\prime}$ E5 $57^{\circ} 35.536^{\prime}$, rocky wadi, 04.16.2008 leg. S. Ilniczky, S. J. Simonyi; 2 exx. /Oman, Gov. Dhofar / N of Mirbat, N17º $01.518^{\prime}$ E54 $47.723^{\prime}$ 59 m 15-24.04.2008 leg. S. Ilniczky, S. J. Simonyi; 1 ex. / OMAN, Gov. Dhofar, Jabal al Quamar / below Mugurah, 42 m, seashore / N16²5.550' E53³0.811' /07.09.2010 / leg. S. Ilniczky, S. J. Simonyi; 1 ex. OMAN, Gov. Dhofar / Jabal al Qara W of Al Mughsayl / N16 $50.535^{\prime}$ E53 $43.349^{\prime} 50$ m, grassy foothill, 30.10.2018 leg. L. Ábrahám, S. Ilniczky, S. J. Simonyi, 10 exx. / OMAN, Gov. Dhofar / Wadi Shaboun / N17³2.83’ E54³8.78' / dry forest 02.05.2019 / leg. L. Ábrahám, S. Ilniczky, G. Körtési; 1 ex. / OMAN, Reg. Al Batinah South / Balad Seet / N23⒒794' E57²3.426' / 914 m oasis, spring / 06.05.2019 / leg. L. Ábrahám, S. Ilniczky, G. Körtési.
} 


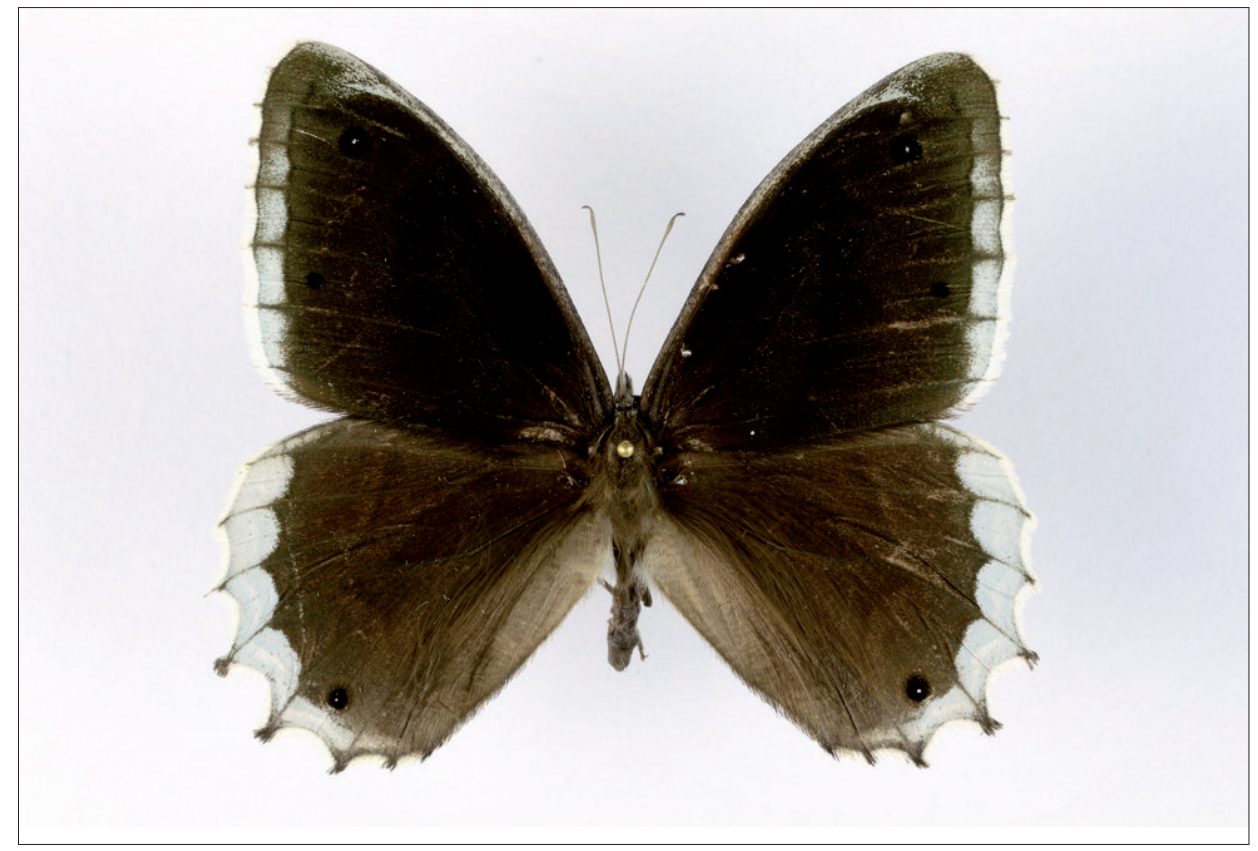

Fig. 17: Hipparchia parisatis (Kollar, 1849) male upper side

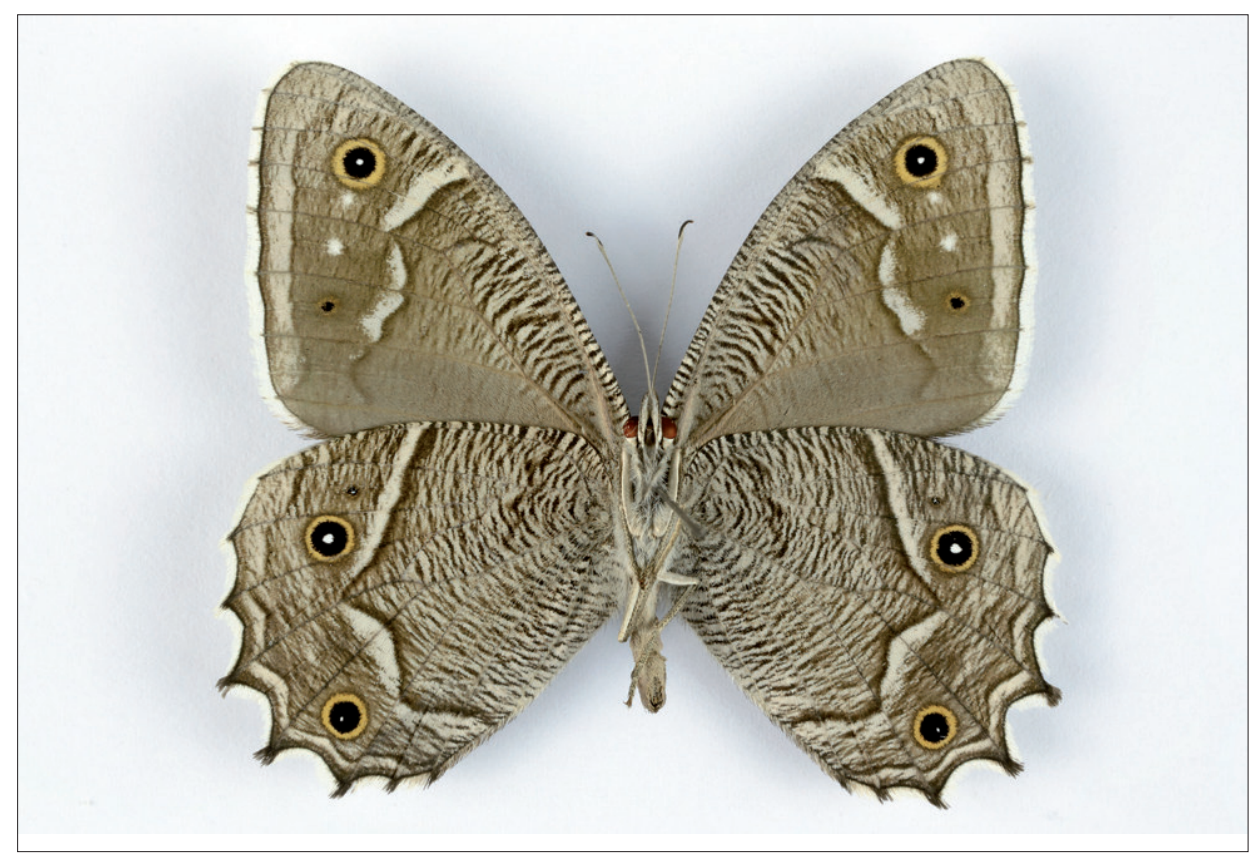

Fig. 18: Hipparchia parisatis (Kollar, 1849) male under side 
Distribution: Y. asterope occurs mainly in Africa, the Middle East, and Arabia. In the Mediterranean, it is also found along the southern Turkish coast, in some islands of the East Egean (northwards to Samos Island) and in Cyprus (TshiKoloveTs 2011). It can be found in all parts of Oman.

Remarks: This species is widespread and common in most parts of Oman, especially in the Dhofar Region. The host plants of this small Satyridae butterfly are various Poaceae, such as Poa annua (Tshikolovets 2011).

Charaxinae Guenée, 1865

Charaxes hansali arabica Riley, 1931 (Figs. 18-19)

Material examined: 2 exx. OMAN, Gov. Dhofar, Jabal al Qamar, near Mugurah, N16²47.463' E53²8.364' 896 m, forested hillside, 22.04.2009 leg. S. Ilniczky, S. J. Simonyi; 1 ex. OMAN, Gov. Dhofar, Wadi Darbat, N1705.152' E54²6.815' 190 m, bushy pasture, 11.07.2010 leg. S. Ilniczky, S. J. Simonyi; 9 exx. OMAN, Gov. Dhofar / $8 \mathrm{~km} \mathrm{~S}$ of Mugurah / N16 ${ }^{\circ} 46.246^{\prime}$ E53 ${ }^{\circ} 28.488^{\prime} / 480 \mathrm{~m}$ dry forested area / 29.04.2019 / leg. L. Ábrahám, S. Ilniczky, G. Körtési.

Distribution: The nominate subspecies is endemic to the Horn of Africa (Ethiopia, Somalia), while further subspecies are found in other arid areas in East Africa. In the Arabian Peninsula, two subspecies occur with allopatric distribution: $C$. hansali arabica and C. h. yemeni Turlin, 1998, with the latter being endemic to Yemen (WILliams 2019).

Remarks: Altogether 186 Charaxes Ochsenheimer, 1816 species are known to occur in the Afrotropical region with many similar species in various species groups. $C$. hansali arabica occurs only in Dhofar, where it is moderately common in suitable habitats: foothill savannah and scrubland. The possible host plant of this remarkable butterfly is Salvadora persica.

Charaxes varanes bertrami (Riley, 1931)

Material examined: 2 exx. / OMAN, Gov. Dhofar, Jabal al Qamar, below Mugurah, N16 ${ }^{\circ} 45.950^{\prime}$ E5 $53^{\circ} 30.811^{\prime}$ $42 \mathrm{~m}$, seashore with spring and grove, 07.09.2010 leg. S. Ilniczky, S. J. Simonyi; 1 ex. / OMAN, Gov. Dhofar / 3 km W of Rakhyuth / N16²5.225' 53²3.905' / 36 m wadi / 2018.10.31. / leg. L. Ábrahám, S. Ilniczky.

Distribution: The nominate subspecies is confined to Southern Africa, while the distribution of ssp. vologeses covers almost the rest of mainland sub-Saharan Africa (WiLliams 2019). It is among the most widespread Charaxes species. C. varanes bertrami, occurring only in Dhofar, was the only population known from Arabia for a very long time, but another population was found in Yemen, which is considered to belong to C. varanes vologeses (LARSEN 1982).

Remarks: It is a quite common butterfly in the woodlands and the coastal wadis there. Both $C$. hansali arabica and $C$. varanes bertrami are attracted to rotten-fermented fruit and dung.

Nymphalinae Rafinesque, 1815

Junonia hierta cebrene (Trimen, 1870)

Material examined: 1 ex. / OMAN, Gov. Dhofar, Jabal al Qamar / seashore below Mugurah, $42 \mathrm{~m} /$ N16²5.550' E5330.811' / 09.07.2010 / leg. S. Ilniczky, S. J. Simonyi; 3 exx. / OMAN, Gov. Dhofar, Jabal al Qara, W of Al Mughsayl / N16²51.243' E53²43.149' 496 m, grassy hillside / 10.07.2009 / leg. S. Ilniczky, S. J. Simonyi; 2 exx. / OMAN, Gov. Dhofar / 3 km N of Quiroon Hairitti / N17²16.362' E5404.949' 813 m dry 


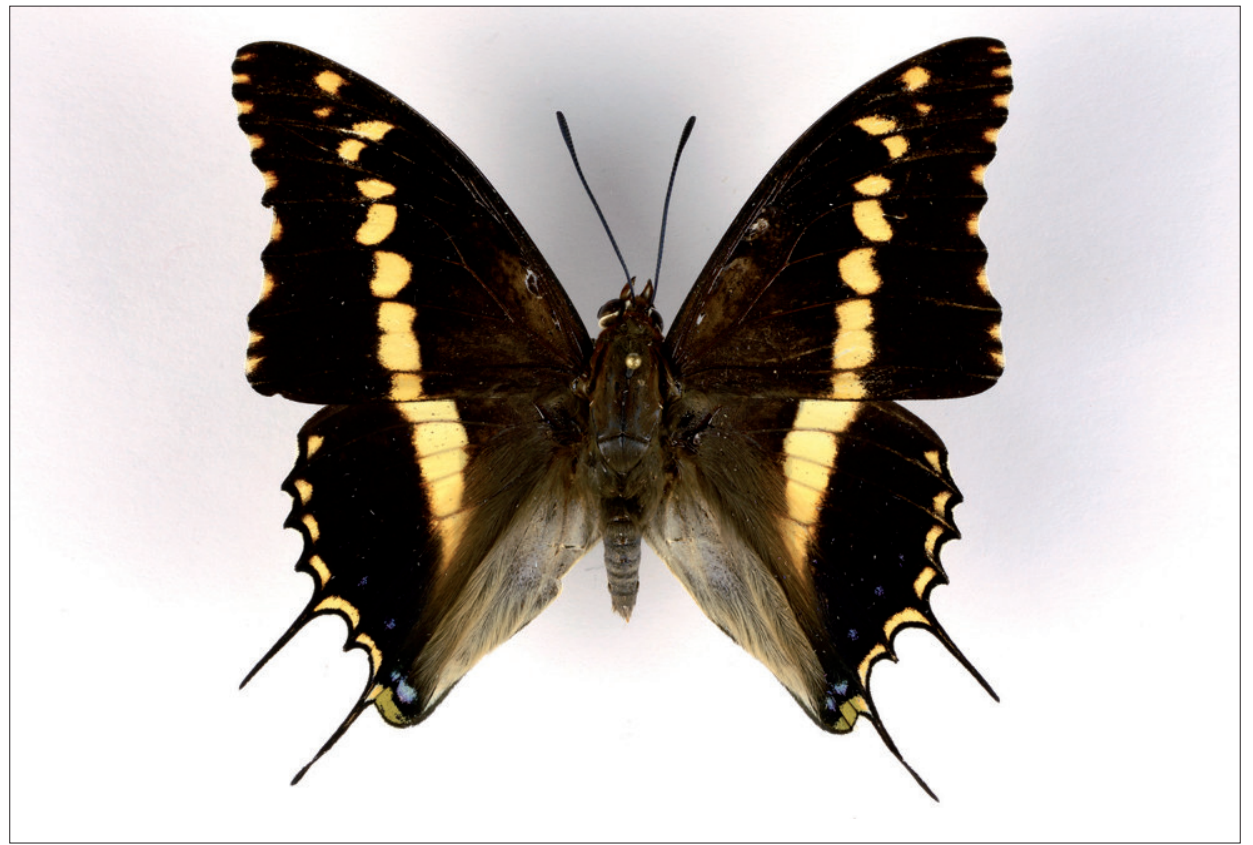

Fig. 18: Charaxes hansali arabica Riley, 1931 male upper side

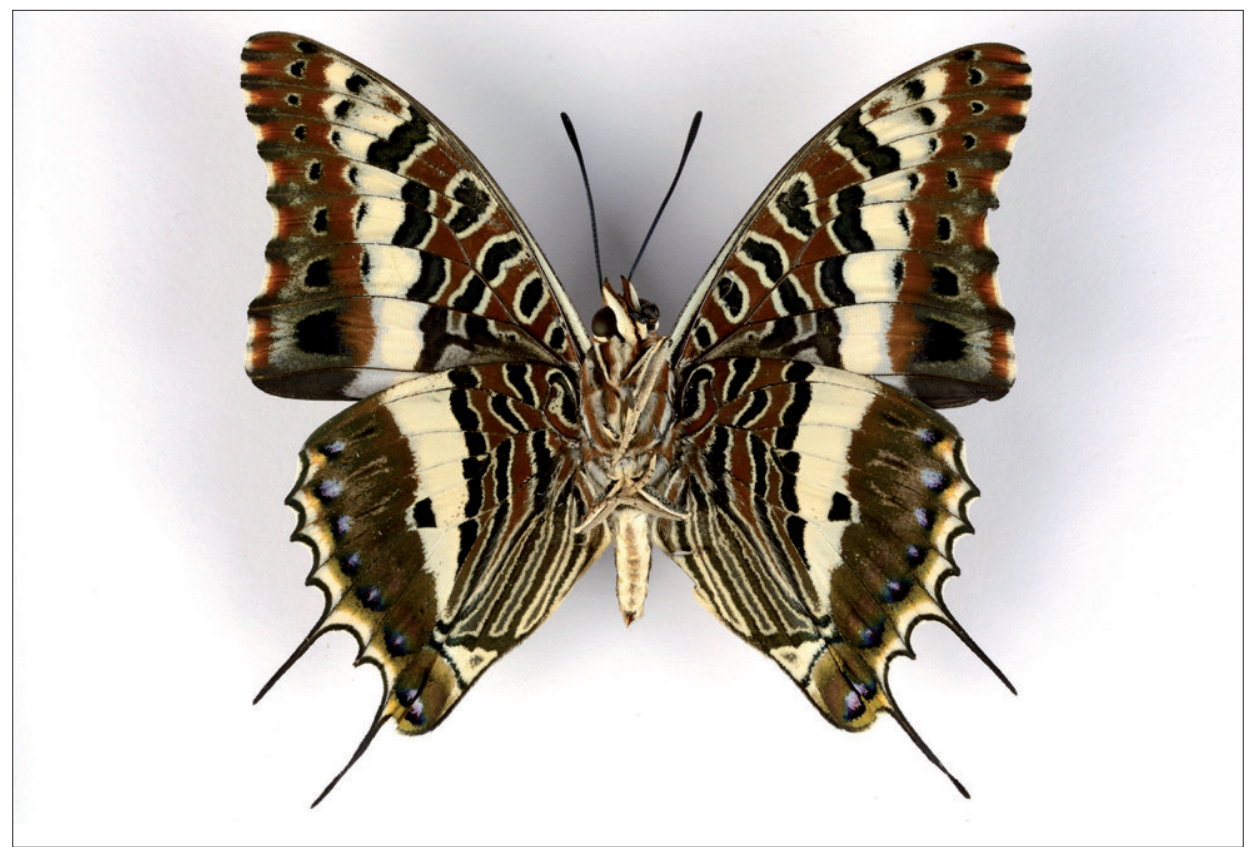

Fig. 20: Charaxes hansali arabica Riley, 1931 male under side 
grassland / 28.10.2018 / leg. L. Ábrahám, S. Ilniczky; 1 ex. / OMAN, Gov. Dhofar / 3 km W of Rakhyuth / N16 ${ }^{\circ} 45.225^{\prime}$ E53ํ2 $3.905^{\prime} / 36$ m wadi / 31.10.2018 / leg. L. Ábrahám, S. Ilniczky; 1 ex. / OMAN, Gov. Dhofar / Wadi Shaboun / N17³2.83’ E54³8.78' / 386 m dry forest / 01.05.2019 / leg. L. Ábrahám, S. Ilniczky, G. Körtési; 1 ex. / OMAN, Reg. Al Batinah South / Balad Seet / N23¹1.794' E57²3.426' / 914 m oasis, spring / 06.05.2019 / leg. L. Ábrahám, S. Ilniczky, G. Körtési.

Distribution: The subspecies cebrene (Trimen, 1870) occurs in all over sub-Saharan Africa, north to Lebanon and the Arabian Peninsula. The nominate subspecies is distributed in the tropical and subtropical areas of Asia, eastward to Indo-China. The African subspecies is common in most of Oman, except the north, where it is quite local and rare.

Remarks: Both Junonia hierta cebrene and the following species J. orithya here species share similar habitats, biology, and behaviour. They usually fly close to the ground, often land on leaves, bushes and even on bare ground to sunbathe, they are attracted to flowers. Males of both species are often seen protecting their territories in open areas but not usually in hilltop position. They also express similar courtship and mating flight, flying very high and rapidly in a spiral line (LARSEN \& LARSEN 1980). Both have a migratory habit (LARSEN 2005) or they rather extend their breeding range temporarily into wetter tropical areas during the dry season (Sáfián pers. obs.). The main host plants of $J$. hierta cebrene are Asteracantha and Barleria species (LARSEN \& LARSEN 1980).

\section{Junonia orithya here Lang, 1884}

Material examined: 2 exx. OMAN, Gov. Dhofar, Jabal al Qamar, E of Mugurah, N16²45.768' E53³0.661' 16 m, seashore,15-16.10.2009 leg. S. Ilniczky, S. J. Simonyi; 2 exx. OMAN, Gov. Dhofar, Jabal al Qara, W of Al Mughsayl N1651.243' E5343.149' 496 m 07.07.2010 leg. S. J. Simonyi, S. Ilniczky; 2 exx. / OMAN, Gov. Dhofar / 3 km N of Quiroon Hairitti / N17²16.362' E5404.949' 813 m dry grassland / 28.10.2018 / leg. L. Ábrahám, S. Ilniczky; 1 ex. / OMAN, Gov. Dhofar / 7 km W of Mirbat / N17001.578' E54³9.322' / 31 m seeshore, sand dunes / 03.11.2018 / leg. L. Ábrahám, S. Ilniczky; 1 ex. / OMAN, Gov. Al Dakhiliyah / Misfah, Jabal Shams / N23⒕154' E5708.987' / 1400 m rocky wadi / 05.05.2019 / leg. L. Ábrahám, S. Ilniczky, G. Körtési.

Distribution: The nominate subspecies spread from the Middle East to India, across Southeast Asia to North Australia. J. orithya ssp. madagascariensis Guenée, 1865 is distributed widely in sub-Saharan Africa and Madagascar. It is one of the few species, which is distributed in almost the whole Arabian Peninsula, including Oman (PoLAK \& VEROVNIK 2009).

Remarks: On the species' behaviour see notes above in J. hierta cebrene. The host plants of J. orithya in Asia are Barleria and Justicia species, also Blepharis ciliaris, Lippia nodiflora, Convulvulus arvensis (TshiKolovets 2011). In Africa larvae of ssp. madagascariensis feed on various Convolvulaceae, Scrophulariaceae and Acanthaceae (LARSEN 1991, 2005), no specific information is known for the Arabian subspecies.

\section{Melitaea deserticola Oberthür, 1909}

Material examined: 3 exx. / OMAN, Gov. Dhofar, Jabal al Qara, W of Al Mughsayl N16²51.243' E5343.149' 496 m, grassy hillside with shrubs 13.10.2009 leg. S Ilniczky, S. J. Simonyi.

Distribution: This species occurs in Northern Africa (from Morocco to Lybia), certain parts of the Middle East and the Arabian Peninsula. In Oman, it is restricted to Dhofar. 
Remarks: In Dhofar, it is local, not so common. The host plants are probably Kickxia species (LARSEN \& LARSEN 1980). The taxonomy status of this species is rather problematic. The populations in the Middle East and Arabia are considered a different subspecies, M. deserticola macromaculata Belter, 1934 but even the Omani and Yemeni populations are sometimes also reckoned to belong to other subspecies, $M$. deserticola scotti Higgins, 1941. To make the case even interesting, the southwestern Arabian populations were thought to belong to $M$. abyssinica Oberthür 1909 for a long time (LARSEN \& LARSEN 1980, LARSEN 1982).

Vanessa cardui (Linnaeus, 1758)

Material examined: 3 exx. / OMAN, Reg. Al Dakhiliyah / Misfah, Jabal Shams / N23⒕154' E5708.987' / 1400 m rocky wadi / 05.05.2019. / leg. L. Ábrahám, S. Ilniczky, G. Körtési; 2 exx. / OMAN, Reg. Al Batinah South / Balad Seet / N23⒒794' E57²3.426' / 914 m oasis, spring / 06.05.2019 / leg. L. Ábrahám, S. Ilniczky, G. Körtési.

Distribution: The Painted Lady is a cosmopolitan butterfly. It is one of the most widespread insects of the world: it ranges all continent, excepting Antarctica, though it is very limited in Australia (only the southwestern coastal area) and South-America (only in Venezuela) (TshiKoloveTs 2011). It is a great flier and an exceptional migrant species, that can reach enormous territories of the world. Although, in Europe, it can breed and survive the winter only in the Mediterranean Region and North Africa, where the butterflies populate the continent every year. In the Arabian Peninsula, the case is exactly the opposite: they can breed permanently only in the more temperate areas. In Oman, it is a rather scarce butterfly, but the abundance of it strongly depends on the weather conditions and the migration waves.

Remarks: The larvae feed on different Carduus, Cirsium, Urtica, and Malvae species, depending on the territory, in Oman, mostly Carduus and Malvae (LARSEN \& LARSEN 1980).

Biblidinae Boisduval, 1833 Byblia ilithyia (Drury, 1773) (Figs. 20-21)

Material examined: 1 ex. / OMAN, Gov. Dhofar, Jabal al Qara, W of Al Mughsayl, N1651.824' E5343.217' 76 m 13.10.2009 leg. S. Ilniczky, S. J. Simonyi; 1 ex. OMAN, Gov. Dhofar, Jabal al Qara, W of Al Mughsayl, N16 $51.243^{\prime}$ E53º43.149' 496 m, grassy escarpment with many shrubs above the high road, 13.10.2009 leg. S. Ilniczky, S. J. Simonyi; 1 ex. OMAN, Gov. Dhofar, Jabal al Qara, W of Al Mughsayl, N1650.450' E53⒋648' 644 m, grassy hillside, 07.07.2010 leg. S. Ilniczky, S. J. Simonyi; 1 ex. / OMAN, Gov. Dhofar, Jabal al Qamar / seashore below Mugurah, 42 m / N1645.550' E53³0.811' / 09.07.2010 / leg. S. Ilniczky, S. J. Simonyi; 2 exx. / OMAN, Gov. Dhofar / $11 \mathrm{~km}$ W of Al Mughsayl / N16 $50.535^{\prime}$ E53 ${ }^{\circ} 43.349^{\prime} 50$ m, foothill, bushy / 29.10.2018 / leg. L. Ábrahám, S. Ilniczky, S. J. Simonyi; 3 exx. / OMAN, Gov. Dhofar / 3 km W of Rakhyuth / N16²5.225' E53²3.905' / 36 m, wadi / 31.10.2018 / leg. L. Ábrahám, S. Ilniczky; 1 ex. / OMAN, Gov. Dhofar / $18 \mathrm{~km}$ from roadside between Sadah and Mirbat / N179.542' E5452.774' / 529 m dry rocky vegetation / 02.11.2018 / leg. L. Ábrahám, S. Ilniczky; 1 ex. / OMAN, Gov. Dhofar / Wadi Shaboun / N17³2.83’' E54³8.78' / 386 m dry forest / 01.05.2019 / leg. L. Ábrahám, S. Ilniczky, G. Körtési.

Distribution: The Joker occurs in dry habitats of sub-Saharan Africa, in southwestern Arabia, and also in the western part of India, including Sri Lanka. A closely related taxon, B. anvatara acheloia (Wallengren, 1857) can be found also in Arabia, but it was recorded only in Yemen and Saudi Arabia (south-west) (LARSEN 1982). B. ilithyia has stable populations in Dhofar, but seems to be absent in other regions of Oman. 


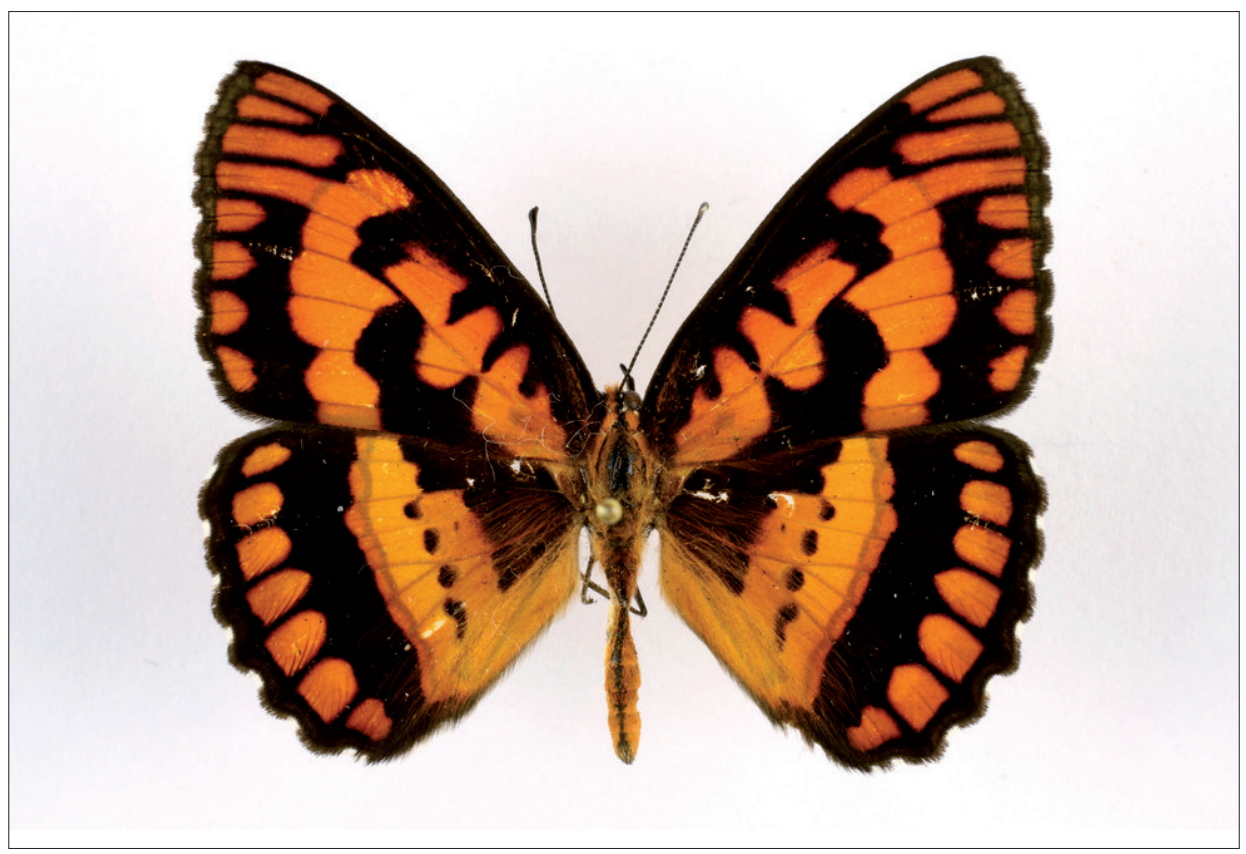

Fig. 21: Byblia ilithyia (Drury, 1773) female upper side

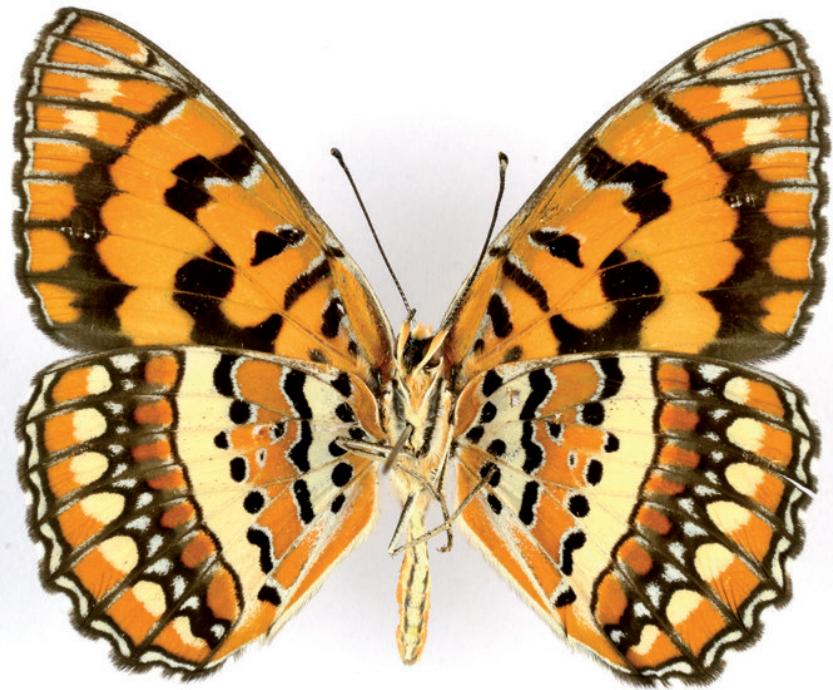

Fig. 22: Byblia ilithyia (Drury, 1773) female under side 
Remarks: In Dhofar, B. ilithyia is a rather common species. The larvae of the species probably feed on various Euphorbiaceae (WILLIAMS 2019).

Pieridae Swainson’, 1820

Coliadinae Swainson, 1821

Eurema hecabe solifera (Butler, 1875) (Fig. 23)

Material examined: 1 ex. OMAN, Reg, Al Batinah South, Ar Rustaq, N2324.003' E57²5.517' 339 m, 04.16.2008 leg. S. Ilniczky, S. J. Simonyi; 1 ex. OMAN, Gov. Dhofar, Jabal al Qamar, E of Mugurah, N16²5.768' E53³0.661' seashore, 16 m 16.10.2009 leg. S. J. Ilniczky, S. J. Simonyi; 2 exx. OMAN, Gov. Dhofar, Jabal al Quamar below Mugurah, N16²5.550' E53³0.811' seashore, $42 \mathrm{~m}, 09.07 .2010$ leg. S. J. Simonyi, S. Ilniczky; 21 exx. / OMAN, Gov. Dhofar, / 2 km E of Rakhyuth / N16²44.968' E5326.256' / 22 m, seashore / 31.10.2018 / leg. L. Ábrahám, S. Ilniczky; 2 exx. OMAN, Gov. Dhofar, Rakhyut, wadi N16²5.225', E53²3.905' 36 m leg. L. Ábrahám. S. Ilniczky, S. J. Simonyi.

Distribution: The nominate subspecies is Asian, while ssp. solifera (Butler, 1875) ranges across Africa, south of the Sahara, also in certain areas of the Arabian Peninsula: mostly southern and southwestern coastal territories. In Oman, it is limited to the Dhofar Region.

Remarks: In Dhofar, the species is quite local. It prefers wet and moist habitats, coastal wadis, scarps. Although it is a weak and fluttering flier, sometimes specimens migrate significant distances. The host plants are Leguminosae, Hypericum and Cassia species (LARSEN 1991, 2005).

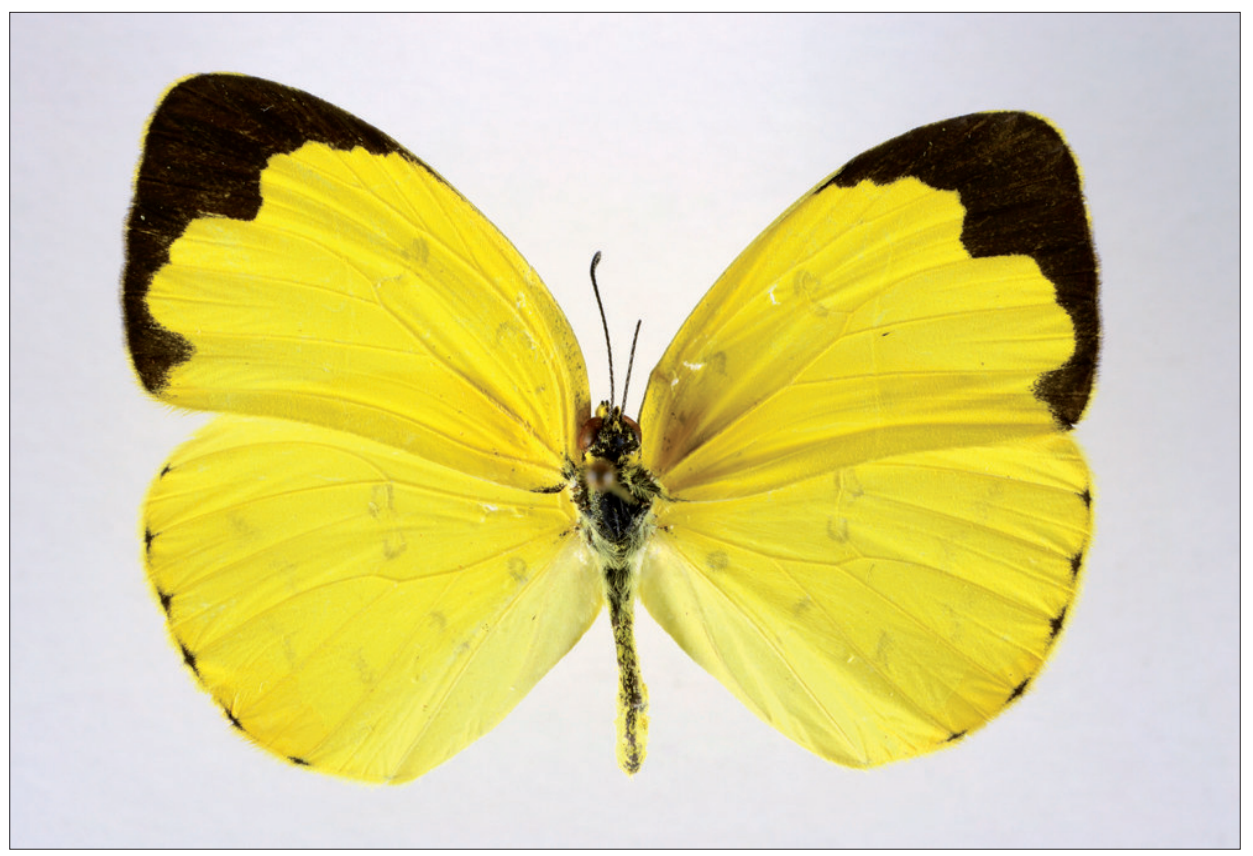

Fig. 23: Eurema hecabe solifera (Butler, 1875) male upper side 
Catopsilia florella (Fabricius, 1775)

Material examined: 1 ex. OMAN, Gov. Dhofar, Jabal al Qamar, seashore below Mugurah, N16 $45.768^{\prime}$ E53³0.461' 16 m, 16.10.2009 leg. S. Ilniczky, S. J. Simonyi; 1 ex. Reg. Al Batinah South, Hubrah, N2336.097' E57 50.252' 172 m, oasis, 17.07.2010 leg. S. Ilniczky, S. J. Simonyi; 1 ex. / OMAN, Gov. Dhofar / 3 km W of Rakhyuth / N16²5.225' E53²3.905' / 36 m wadi / 31.10.2018 / leg. L. Ábrahám, S. Ilniczky; 4 exx. / OMAN, Gov. Dhofar / $18 \mathrm{~km}$ of roadside between Sadah and Mirbat / N179.542' E54 52.774' / 529 m dry rocky vegetation / 02.11.2018 / leg. L. Ábrahám, S. Ilniczky; 2 exx. / OMAN, Gov. Dhofar / Wadi Shaboun / N17³2.83’ E54³8.78' / 386 m dry forest / 01.05.2019 / leg. L. Ábrahám, S. Ilniczky, G. Körtési.

Distribution: The African Migrant is one of the most commonly encountered butterflies on the African continent, although only migrants reach north to the Sahara. It is distributed most part of this continent, also the Arabian Peninsula and certain parts of India and China. The Asian records probably refer to the very similar and hardly distinguishable relative species $C$. pyranthe (Linnaeus, 1758). During the last decades, $C$. florella became established in Madeira and also in the Canary Islands (Aguiar \& WAKEHAM-DAWSON 2001). In Oman, it is a moderately common, but permanent species.

Remarks: The larval food plants are variously cultivated and wild Cassia species (TsHikolovets 2011).

Pierinae Swainson, 1820

Nepheronia buquetii buchanani (Rothschild, 1921)

Material examined: 1 ex. OMAN, Gov. Dhofar, Jabal al Qamar, S of Mugurah N16²45.768' E53³0.663', seashore, 16.10.2009 leg. S. Ilniczky, S. J. Simonyi; 1 ex. / OMAN, Gov. Dhofar, / 8 km S of Mugurah / N16 $45.858^{\prime}$ E532 $28.547^{\prime}$ / 475m dry, forested area / 31.10.2018 / leg. L. Ábrahám, S. Ilniczky; 2 exx. / OMAN, Gov. Dhofar / Wadi Shaboun / N17³2.83’ E54³8.78' / 386 m dry forest / 01.05 .2019 / leg. L. Ábrahám, S. Ilniczky, G. Körtési.

Taxonomic note: Larsen doubts the validity of the subspecies buchanani, but he did not formally invalidate it (LARSEN 2005).

Distribution: The global distribution of this species covers most arid areas of sub-Saharan Africa. It occurs also in the southwestern part of the Arabian Peninsula, including the Dhofar Region (PolAK \& VEROVNIK 2009). It was not found in other parts of Oman so far.

Remarks: N. buquetii is an incredibly fast flier. In-flight, it is nearly impossible to distinguish from the slightly larger males of Catopsilia florella. Rather common in Dhofar, where its larval host plant is Salvadora persica and other Salvadoraceae and Capparaceae (WiLliams 2019).

Colotis antevippe zera (Lucas, 1852)

Material examined: 1 ex. OMAN Prov. Dhofar,Mughsayl N2650.969' E5302.569' 110m foothill, bushy 27.04.2019 leg. L. Ábrahám, S. Ilniczky, G. Körtési.

Distribution: The nominate subspecies is West African, occurring between Mauritania ad Northern Cameroon. Subspecies gavisa (Wallengren, 1857) is distributed from South Africa to Central Tanzania. Subspecies zera (Lucas, 1852) is found from Northern Tanzania, across Kenya, Uganda and Sudan to the Horn of Africa and also to Southern Arabia (LARSEN 2005, WiLLIAMS 2019). 
Remarks: It belongs to the scarcer Colotis species. In Oman, it is restricted to the Dhofar Region, but it also flies in certain parts of Yemen. The larval food plants are unknown in Dhofar, through they feed on various Capparidaceae in Africa (LARSEN \& LARSEN 1980).

\section{Colotis calais (Cramer, 1775)}

Material examined: 3 exx. OMAN, Gov. Dhofar, Jabal al Qara, W of Al Mughsayl, N16²51.243' E5343.149' $496 \mathrm{~m}$, grassy escarpment with many shrubs above the high road, 13.10.2009 leg. S. Ilniczky, S. J. Simonyi; 11 exx. / OMAN, Gov. Dhofar / 3 km W of Rakhyuth / N16²45.225' E53²3.905' / 36 m wadi / 31.10.2018 /

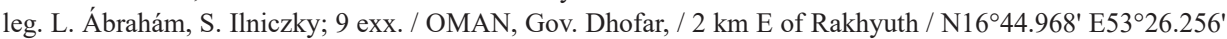
/ 22 m, seashore / 31.10.2018 / leg. L. Ábrahám, S. Ilniczky; 9 exx. / OMAN, Gov. Dhofar / $20 \mathrm{~km} \mathrm{~W} \mathrm{of} \mathrm{Al}$ Mughsayl / N16 $50.051^{\prime}$ E5342.552' / 34 m seashore, dry rocky vegetation with shrubs/ 01.11.2018 / leg. L. Ábrahám, S. Ilniczky, S. J. Simonyi.

Taxonomic note: $C$. calais was treated for a long time as the Afrotropical subspecies of $C$. amata (Fabricius 1775), but according to NAZARI et al. (2011), the two are not conspecific, $C$. amata being purely Asian, and the subspecies calais became the valid specific name of the African taxon.

Distribution: The Small Salmon Arab is distributed from South Africa through the eastern part of the continent along the northern Sahel zone to Mauritania and also the Arabian Peninsula.

Remarks: It is a common butterfly in the Dhofar Region and occurs, but much scarcer in the northern areas of Oman. It inhabits open dry savannahs and arid shrubby areas. The larval food plant is Salvadora persica and Capparaceae species (WiLliams 2019). In suitable habitats, it can be found in vast numbers (LARSEN \& LARSEN 1980).

\section{Colotis danae eupompe (Klug, 1829)}

Material examined: 6 exx. OMAN, Gov. Dhofar, Jabal al Qamar, below Mugurah, N1645.950' E53³0.811' $42 \mathrm{~m}$, seashore with spring and grove, 09.07.2010 leg. S. Ilniczky, S. J. Simonyi; 3 exx. / OMAN, Gov. Dhofar, / 2 km E of Rakhyuth / N1644.968' E53²6.256' / 22 m, seashore / 31.10.2018 / leg. L. Ábrahám, S. Ilniczky; 1 ex. / OMAN, Gov. Dhofar / Wadi Shaboun / N17³2.83’ E54³8.78' / 386 m dry forest / 01.05.2019 / leg. L. Ábrahám, S. Ilniczky, G. Körtési.

Distribution: The nominate subspecies is Asian, while subspecies eupompe (Klug, 1829) ranges from Mauritania, through the sub-Saharan Sahel and Sudan savannah zone to the Horn of Africa and Arabia (LARSEN 2005, Williams 2019). A few isolated populations occur also in Egypt and Jordan. It is widespread and rather common in Dhofar, but very local in Northern Oman.

Remarks: Habitats of this species include sparse dry woodlands, forest edges, savannah, open grasslands and even semi-desert (WiLliams 1973). The main host plants are Cadaba and Capparis species (TshiKolovets 2011, WiLliams 1973) and also Boscia senegalensis (LARSEN 2005).

\section{Colotis daira daira (Klug, [1829])}

Material examined: 1 ex. OMAN, Dhofar, Jabal al Qamar, below Mugurah, N1645.950' E 53³0.811' 42 m, seashore with spring and grove, 09.07.2010 leg. S. J. Simonyi, S. Ilniczky.

Distribution: The nominate subspecies is confined to the southern and western parts of the Arabian Peninsula while other subspecies are distributed in the northern dry zone of sub-Saharan Africa and in the Horn of Africa to Northern Kenya (Williams 2019). 
Remarks: In Dhofar, it obviously belongs to the scarcer Colotis species (BALLETTO \& LARSEN 1985). The main larval host plants are most likely Cadaba species (LARSEN \& LARSEN 1980).

Colotis evarne (Klug, [1829])

Material examined: 3 exx. OMAN, Dhofar, Jabal al Qamar, below Mugurah, N16²45.950' E53³0.811' 42 m, seashore with spring and grove, 09.07.2010 leg. S. J. Simonyi, S. Ilniczky; 1 ex. $11 \mathrm{~km} \mathrm{~W} \mathrm{of} \mathrm{Al} \mathrm{Mughsayl} \mathrm{/}$ N16 50.535' E534⒊349' 50 m, foothill, bushy / 29.10.2018 / leg. L. Ábrahám, S. Ilniczky; 3 exx. / OMAN Prov. Dhofar, / 2 km E of Rakhyuth / N16²44.968' E53²6.256' / 22 m seashore / 31.10.2018 / leg. L. Ábrahám, S. Ilniczky; 14 exx. / OMAN Prov. Dhofar / 20 km W of Al Mughsayl / N1650.051' E53² $42.552^{\prime} / 34 \mathrm{~m}$ seashore, dry rocky vegetation / 01.11.2018 / leg. L. Ábrahám, S. Ilniczky.

Taxonomic note: $C$. evarne (Klug, [1829]) was previously listed as a subspecies of $C$. eucharis (Fabricius, 1775). However, the latter is an Asian species and C. evarne was listed as a valid species in NAZIRI et al. (2011).

Distribution: C. evarne is distributed widely in the northern dry zone of sub-Saharan Africa between Mauritania and Tanzania, it also reaches Southern Arabia in the northeast. In Oman, the species can be found commonly in Dhofar, only a few specimens are known from the northern part of the country.

Remarks: In Dhofar, it is rather common around Cadaba bushes, the main host plant of this species (LARSEN \& LARSEN 1980, LARSEN 1991). They prefer bushy and open, dry areas.

\section{Colotis fausta vi (Swinhoe, 1884) (Fig. 24)}

Material examined: 1 ex. / OMAN, Gov. Dhofar / 20 km W of Mughsayl / N1650.051' E5342.552' / 34 m seashore, dry rocky vegetation / 01.11.2018 / leg. Ábrahám L. S. Ilniczky, S. J. Simonyi; 2 exx. / OMAN, Reg. Al Batinah South / Balad Seet / N23¹1.794' E57²3.426' / 914 m oasis, spring / 06.05.2019 / leg. L. Ábrahám, S. Ilniczky, G. Körtési.

Distribution: Currently the populations in the southern Arabian Peninsula are recognized as subspecies vi (Swinhoe, 1884), while the nominate form flies Israel via Syria to Afganistan and India, but WiLLIAms (2019) lists also from Chad, which is highly improbable, given its biogeographic distinction and LARSEN (2005) also does not list the species from West Africa. The subspecies mijurtenia Carpenter, 1951 is known to occur only in the Horn of Africa (WILliams 2019). In Oman, it is a scarce and rarely seen species.

Remarks: The larval host plants are like in other Colotis species: Capparis species, mostly C. spinosa and C. mucronifolia in Arabia (LARSEN \& LARSEN 1980).

\section{Colotis halimede (Klug, [1829]) (Fig. 25)}

Material examined: 6 exx. / OMAN, Gov. Dhofar, W of Al Mughsayl, N1651.824', E53²43.217' 76 m, rocky gorge across the main road,13.10.2009 leg. S. Ilniczky, S. J. Simonyi; 1 ex. OMAN, Gov. Dhofar, Jabal Samhan, Wadi Shaboun, N17³.283' E54³3.678' 389 m, rocky forest, 13.07.2010 leg. S. Ilniczky, S. J. Simonyi; 1 ex. / OMAN, Gov. Dhofar / 20 km W of Al Mughsayl / N16 $50.051^{\prime}$ E53 $42.552^{\prime} / 34$ m seashore, dry rocky vegetation / 01.11.2018 / leg. L. Ábrahám, S. Ilniczky; 1 ex. / OMAN, Gov. Dhofar / 18 km from roadside between Sadah and Mirbat / N179.542' E54 52.774' / 529 m dry rocky vegetation / 02.11.2018 / leg. L. Ábrahám, Ilniczky S.

Distribution: The distribution of this species covers the northern dry savannah and Sahel zone in sub-Saharan Africa from Senegal, across Central Africa to the southwest- 


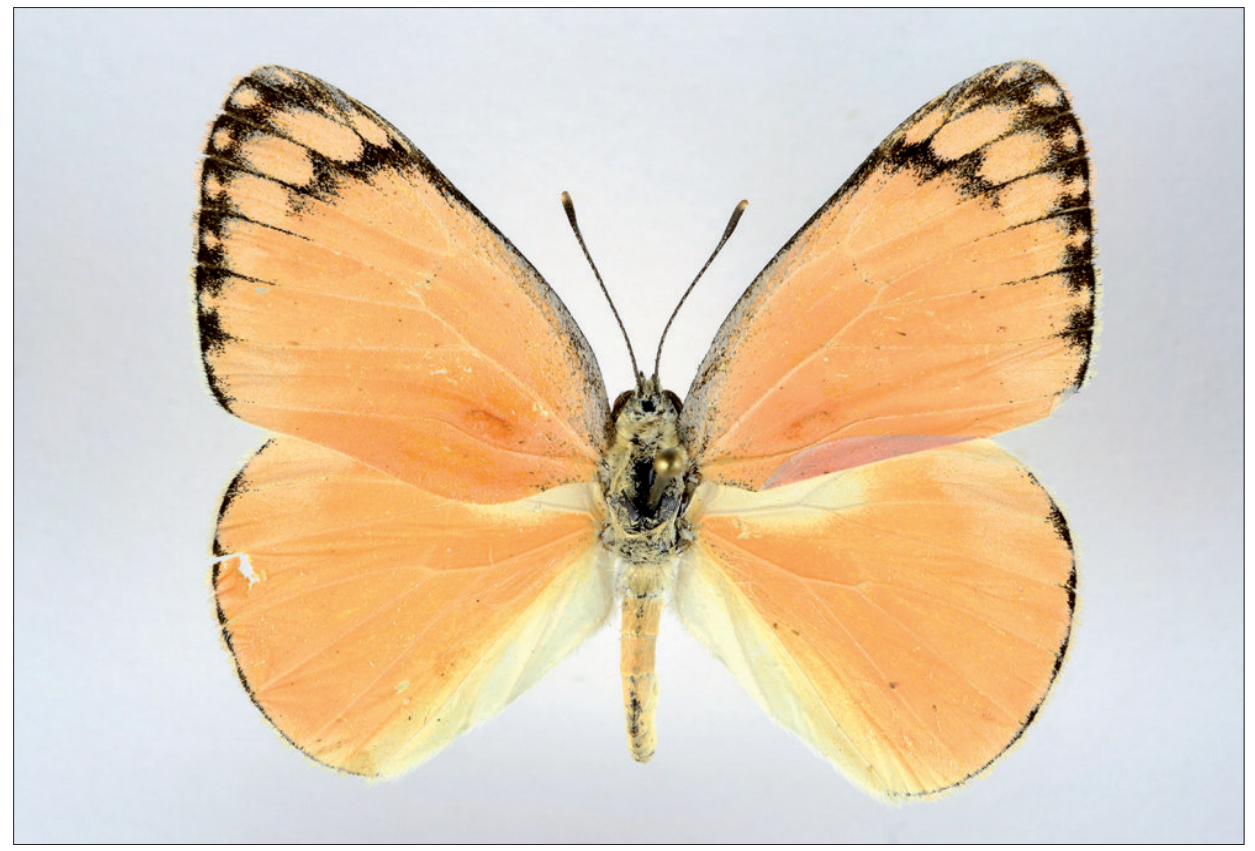

Fig. 24: Colotis fausta vi (Swinhoe, 1884) male upper side

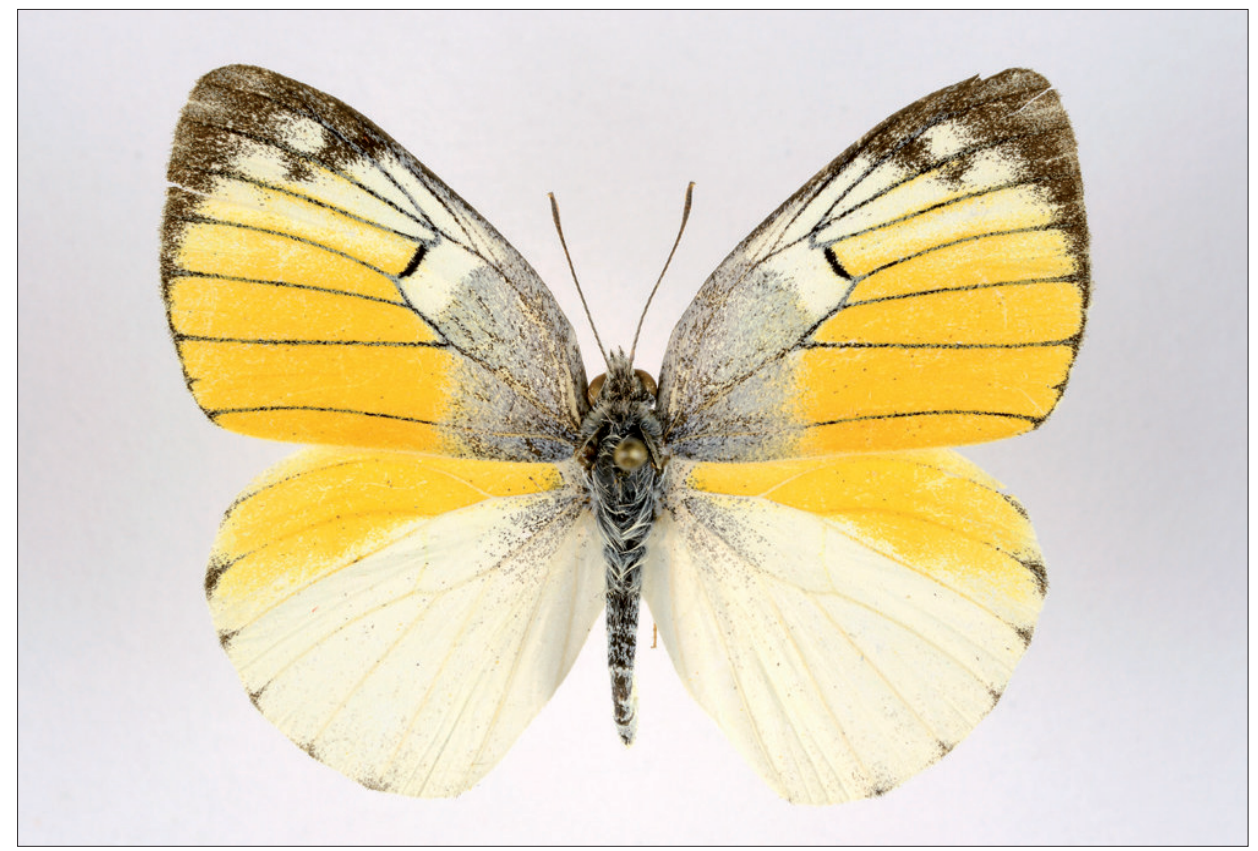

Fig. 25: Colotis halimede (Klug, [1829]) male upper side 
ern part of Arabia. It occurs in distinct populations in Kenya (ssp. restricta Talbot, 1939) and Tanzania (australis Talbot, 1939). In Oman, C. halimede is limited to the Dhofar region.

Remarks: It prefers dry savannah habitats, but in Dhofar they can be found mostly in the wadis, where it is moderately common. These populations were discovered only in 1977 (LARSEN \& LARSEN 1980). The larval host plants are Cadaba species (LARSEN 2005).

\section{Colotis liagore (Klug, 1829)}

Material examined: 2 exx. / OMAN, Reg. Ad Dakhiliya, E of Al Hamra, N23º3.978', N57²2.687', 653 m, roadside, 28.04.2008 / leg. S. J. Simonyi, S. Ilniczky; 3 exx. / OMAN, Reg. Ad Dakhiliya, 2 km W of Al Hamra / N2307.927' E57²5.020' stony pasture (almost without grasses) 28.04.2008 leg. S. J. Simonyi, S. Ilniczky; 6 exx. OMAN, Reg. Al Batinah South, Ar Rustaq, N23²4.003' E57²5.517' oasis, 339 m, 16.04.2009 leg. S. J. Simonyi, S. Ilniczky; 6 exx. / OMAN, Reg.. Al Batinah South / Balad Seet / N23¹1.794' E57²3.426' / 914 m oasis, spring / 06.05.2019 / leg. L. Ábrahám, S. Ilniczky, G. Körtési.

Distribution: In sub-Saharan Africa, C. liagore is distributed in the Sahel zone between Mauritania and Somalia. It occurs also in the Arabian Peninsula reaching in Pakistan (Balochistan) as its eastern limits (LARSEN 2005). It is also found in North Africa with records in Algeria (TenNent 1996) and Morocco (VEROVNIK et al. 2018). In Oman, it can be found in Northern Oman and in Dhofar.

Remarks: In Northern Oman, the Desert Orange Tip is a relatively common species. It was first reported from Dhofar by POLAK \& VEROVNIK (2009). The larval host plants in Oman are Maerua crassifolia and Capparis cartilaginea (LARSEN \& LARSEN 1980, LARSEN 1982).

\section{Colotis phisadia (Godart, 1819)}

Material examined: 11 exx. / OMAN, Reg. Ad Dakhiliya, E of Al Hamra / N2303.978' E57²2.687' 653 m, bushy along the road, 28.04.2008 / leg. S. Ilnitzky, S. J. Simonyi; 1 ex. / OMAN, Reg. Al Batinah South, Nakhl oasis, N2325.151' E5749.244' 244 m, 11.10.2009 leg. S. Ilniczky, S. J. Simonyi; 1 ex. / OMAN, Gov. Dhofar, Jabal al Qara, / $20 \mathrm{~km}$ W of Al Mughsayl / N16 ${ }^{\circ} 50.051^{\prime}$ E53 ${ }^{\circ} 42.552^{\prime} / 34$ m seashore, dry rocky vegetation with shrubs/ 01.11.2018 / leg. L. Ábrahám, S. Ilniczky, S. J. Simonyi; 1 ex. / OMAN, Reg. Al Batinah South / Balad Seet / N23⒒794' E57²3.426' / 914 m oasis, spring / 06.05.2019 / leg. L. Ábrahám, S. Ilniczky, G. Körtési.

Distribution: The species is distributed across the sub-Saharan Sahel zone between Mauritania and Ethiopia through the Arabian Peninsula to the driest, the northernmost part of India (LARSEN 2005). In the north, it reaches also the Sinai Peninsula and Egypt.

Remarks: It is a common butterfly in the Dhofar region and also in Northern Oman. It inhabits open dry savannah and arid bushy areas and is an occasional migrant (LARSEN \& NAKAmURA 1983). The larval food plant is Salvadora persica (Tshikolovets 2011). 


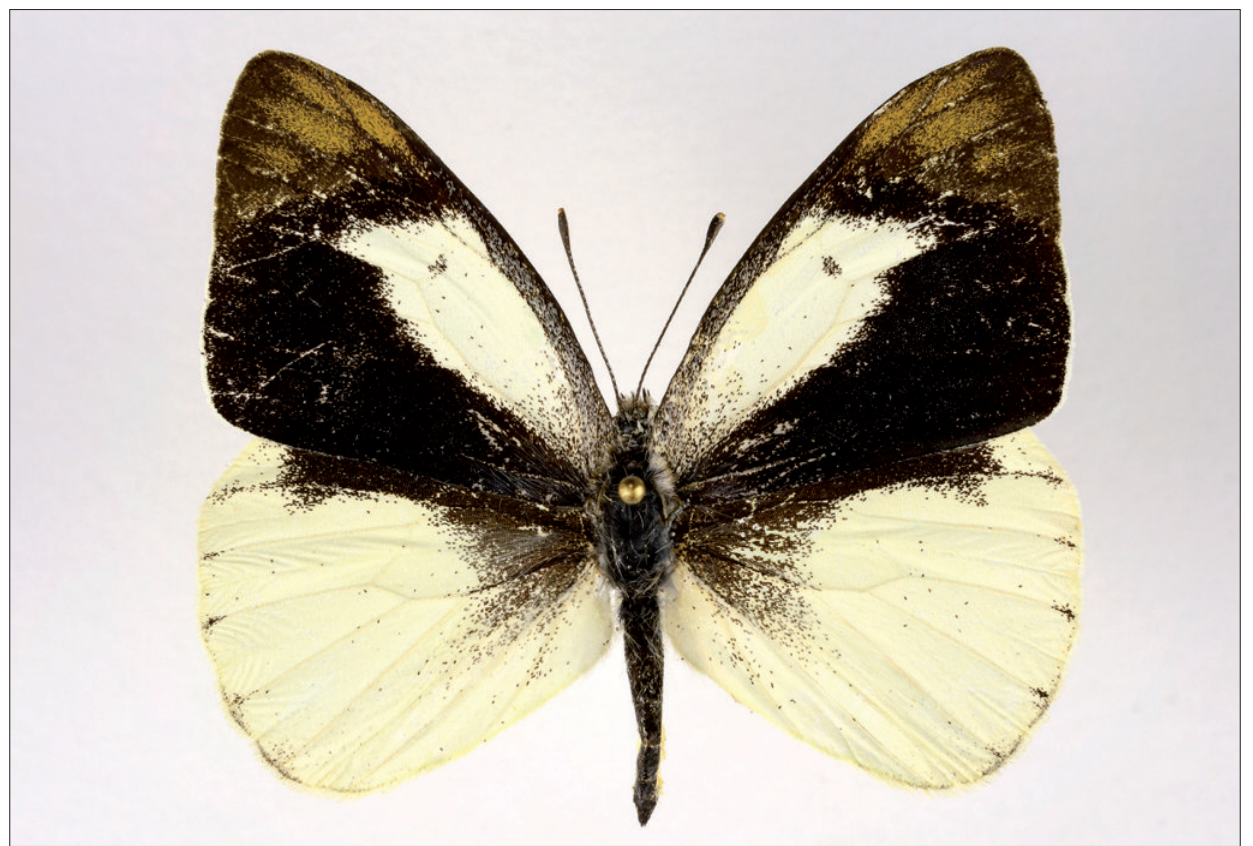

Fig. 26: Teracolus eris contractus (Gabriel, 1954) male upper side

Teracolus eris contractus (Gabriel, 1954) (Fig. 26)

Material examined: 1 ex. / OMAN Prov. Dhofar / 20 km W of Al Mughsayl / N16 50.051' E53²42.552' / 34 $\mathrm{m}$ seashore, dry rocky vegetation / 01.11.2018 / leg. L. Ábrahám, S. Ilniczky; 5 exx. OMAN, Dhofar, Jabal

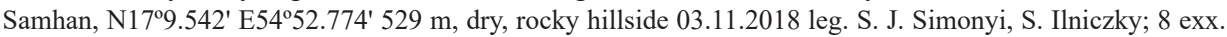

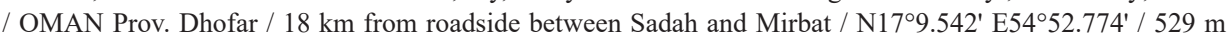
dry rocky vegetation / 02.11.2018 / leg. L. Ábrahám, S. Ilniczky.

Taxonomic note: The species was published under various generic names, described in Pontia Fabricius, 1807 (Klug, [1829-45]), but was most often referred to as a species of Colotis (incl. LARSEN 1985), until NAZARI et al. 2011. have moved a small group of fastflying species with distinctively acute forewing apex to Teracolus Swainson, [1833], based on molecular evidence.

Distribution: T. eris eris occurs throughout the sub-Saharan savannah zone, south to South Africa (LARSEN 2005). The subspecies contractus (Gabriel, 1954) is endemic to Yemen and Oman. In Oman, it can be found only in the Dhofar Region.

Remarks: The distribution of the Banded Gold Tip reaches its northern edge in Dhofar, Oman. Here, it is local and rather scarce. The populations are limited to the localities, where the host plant, Boscia species can be found (LARSEN \& LARSEN 1980).

\section{Pinacopteryx eripha tritogenia (Klug, [1829]) Fig. 27)}

Material examined: 2 exx. OMAN, Gov. Dhofar, Jabal al Qara, W of Al Mughsayl, N1651.243' E5343.149' 496 m, grassy escarpment, 13.10.2009 leg. S. Ilniczky, S. J. Simonyi; 1 ex. OMAN, Dhofar, Jabal Samhan, N17³.83' E54³8.78' 389 m, dry, rocky hillside and valley 13.07.2010 leg. S. Ilniczky, S. J. Simonyi; 5 exx. / 


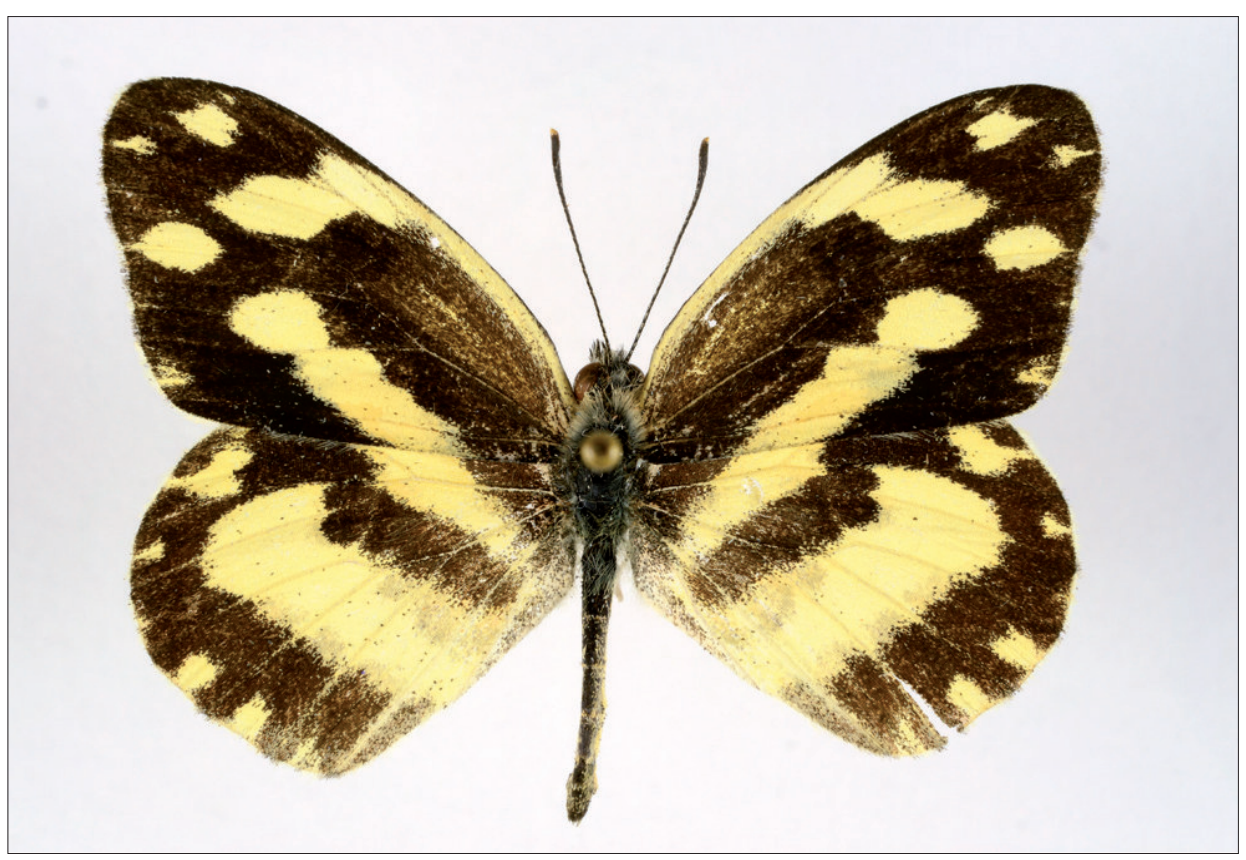

Fig. 27: Pinacopteryx eripha tritogenia (Klug, [1829]) male upper side

OMAN, Gov. Dhofar, Jabal al Qamar / 3 km W of Rakhyuth / N16 $45.225^{\prime}$ E53 $23.905^{\prime}$ / 36 m wadi / 31.10.2018 / leg. L. Ábrahám, S. Ilniczky S. J. Simonyi; 3 exx. / OMAN, Gov. Dhofar, Jabal al Qara, / 20 km W of Al Mughsayl / N16 $50.051^{\prime}$ E53⒋ $2.552^{\prime} / 34$ m seashore, dry rocky vegetation / 01.11.2018 / leg. L. Ábrahám, S. Ilniczky; 1 ex. / OMAN, Gov. Dhofar, Jabal Samhan, / 18 km of roadside between Sadah and Mirbat / N17 $9.542^{\prime}$ E5452.774' / 529 m dry rocky vegetation / 2018.11.02. / leg. L. Ábrahám, S. Ilniczky.

Distribution: The nominate subspecies occurs in Southern Africa, ssp. tritogenia is distributed across the sub-Saharan arid zone from Mauritania to northern Ethiopia and the southern part of Arabia. Other subspecies are found in East Africa and Madagascar (Williams 2019). In Oman, it is limited only to the Dhofar Region.

Remarks: It is a very variable species, with different seasonal, geographical and sexual variations. In Dhofar, it was discovered only in the middle of the 20th century, and quite a few populations are known so far (LARSEN \& LARSEN 1980). The main host plants are various species of Capparaceae: Maerua, Cadaba and Boscia species (WILliams 2019).

\section{Belenois aurota (Fabricius, 1793)}

Material examined: 1 ex. OMAN, Jabal al Akhdar, Birkat Al Sharaf, 2000 m, N23⒒933' E57 20.394', 23.04.2008 leg. S. Ilniczky, S. J. Simonyi; 3 exx. OMAN, Reg. Ad Dakhiliyah, near Al Hamra N23⒊978' E57²2.687' 653 m, 18.04.2008 leg. S. Ilniczky, S. J. Simonyi; 6 exx. OMAN, Reg, Ad Dakhiliyah, near Al Hamra, N23⒊978' E57²2.687' 653 m 28.04.2008 leg. S. Ilniczky, S. J. Simonyi; 1 ex. OMAN, Gov. Dhofar, Jabal al Qara, W of Al Mughsayl, N16²51.243' E5343.149' 496 m, 16.10.2009 leg. S. Ilniczky, S. J. Simonyi;

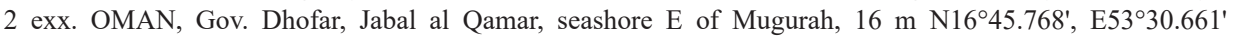
15-16.10.2009 leg. S. J. Simonyi, S. Ilniczky; 1 ex. OMAN, Gov. Dhofar Jabal al Qara, W of Al Mughsayl, N1651.243' E53²3.149' 496 m, 07.07.2010 leg. S. J. Simonyi, S. Ilniczky; 1 ex. / OMAN, Gov. Dhofar / 2 km E of Rakhyuth / N1644.968' E53²6.256' / 22 m, seashore / 31.10.2018 / leg. L. Ábrahám, S. Ilniczky; 8 
exx. / OMAN, Gov. Dhofar / 3 km W of Rakhyuth / N16²45.225' E53²3.905' / 36 m wadi / 31.10.2018 / leg. L. Ábrahám, S. Ilniczky; 6 exx. / OMAN, Gov. Dhofar / $18 \mathrm{~km}$ of roadside between Sadah and Mirbat / N179.542' E5452.774' / 529 m dry rocky vegetation / 02.11.2018 / leg. L. Ábrahám, S. Ilniczky; 11 exx. / OMAN, Gov. Dhofar / Wadi Shaboun / N17³2.83' E54³8.78' / dry forest / 02.05.2019 / leg. L. Ábrahám, S. Ilniczky, G. Körtési; 35 exx. / OMAN, Reg. Al Batinah South / Balad Seet / N23¹1.794' E57²3.426' / 914 m oasis, spring / 06.05.2019 / leg. L. Ábrahám, S. Ilniczky, G. Körtési; 6 exx. / OMAN, Reg. Al Dakhiliyah / Jabal Shams / N23ำ15.339' E57²13.092' / 2138 m rocky and bushy vegetation / 06.05.2019 / leg. L. Ábrahám, S. Ilniczky, G. Körtési.

Distribution: The Brown-veined or Caper White is distributed throughout tropical Africa, Arabia, the Near and the Middle East to the Indian subcontinent and is a regular migrant (WiLliams 2019). In Oman, B. aurota has permanent populations, but immigrants from mainland Africa also regularly reach the Arabian Peninsula and interbreed with the locally bred butterflies (LARSEN \& LARSEN 1980).

Remarks: The wet-season form of this species has stronger black markings along the veins and vivid creamy yellow ground colour on the underside of the hindwing. It is a great flier and a regular migrant. During migrations, specimens can reach as far north as Malta (Tshikolovets 2011). The larvae feed on different species of Boscia, Capparis and Maerua genus (William 2019).

Pontia glauconome (Klug, 1829)

Material examined: 2 exx. / OMAN, Gov. Dhofar / 3 km N of Quiroon Hairitti / N17º16.362' E5404.949' 813 m, dry grassland / 28.10.2018 / leg. L. Ábrahám, S. Ilniczky, S. J. Simonyi; 9 exx. / OMAN Prov. Dhofar, / 2 km E of Rakhyuth / N1644.968' E5326.256' / 22 m, seashore / 31.10.2018 / leg. L. Ábrahám, S. J. Simonyi, S. Ilniczky; 1 ex. / OMAN Prov. Dhofar / 7 km W of Mirbat / N1701.578' E54³9.322' / 31 m seashore, sand dunes / 30.04.2019 / leg. L. Ábrahám, S. Ilniczky, G. Körtési.

Distribution: The global distribution of this species covers the desert and semi-desert areas of North Africa, across the Middle East and the Arabian Peninsula, east to Pakistan and Tajikistan. The Desert White is a rather common butterfly across all parts of Oman.

Remarks: The larval host plants are various Reseda and Ochradenus species. The pupas of this species are able to survive the extreme weather condition even in the worse years. They can stay in this status for several years, waiting for the right conditions to hatch (LARSEN \& LARSEN 1980). This species is probably a vicariant of the closely related $P$. daplidice, which colonises the more temperate habitats, and only occasionally co-occur in the same biotopes (LARSEN 1982).

Lycaenidae Leach, 1815

Aphnaeinae Distant, 1884

Axiocerces harpax kadugli (Talbot, 1935)

Material examined: 1 ex. / OMAN, Gov. Dhofar, / 2 km E of Rakhyuth / N16²4.968' E53²6.256' / 22 m, seashore / 31.10.2018 / leg. L. Ábrahám, S. Ilniczky.

Taxonomic note: ssp. kadugli (Talbot, 1935) could be considered as an extreme dry area ecological form of $A$. harpax distributed in the northern Sahel zone across the continent, rather than a subspecies (LARSEN 2005), but it was not formally invalidated.

Distribution: The nominate subspecies is distributed in large territories of the northern savannah zone of Western Africa, with further subspecies in Central and Eastern Africa. 
It also penetrates into the Guinea-Congolian forest zone. In Oman, ssp. kadugli occurs in the Dhofar Region, where it is moderately common, though it was discovered only in 1977 (LARSEN 1977).

Remarks: The main host plants of the Common Scarlet are Acacia species (LARSEN \& LARSEN 1980).

\section{Cigaritis acamas (Klug, 1834)}

Material examined: 1 ex. / OMAN, Al Batinah South, Ar Rustaq / N2324.003' E57²5.517' 339 m, oasis/ 16.04.2008 / leg. S. Ilniczky, S. J. Simonyi.

Taxonomic note: In many publications, the species appears in the genus Apharitis Riley, 1925, however, the genus was first synonymized with Spindasis Wallengren, 1857 (HEATH 1997), which was later synonymized with Cigaritis Donzel, 1848 (HEATH et al. 2002)

Distribution: Its distribution range covers the Central Sahara Region, in the north it reaches South Algeria, South Lybia, most of coastal parts of the Middle East, South Turkey, Cyprus, the Arabian Peninsula and Pakistan in the east (Tshikolovets 2011). In Oman, it was found only in a few locations.

Remarks: It is a rare and local butterfly in Oman.

Polyommatinae Swainson, 1827

Anthene amarah (Guérin-Méneville, 1847)

Material examined: 1 ex. / OMAN, Gov. Dhofar / 3 km W of Rakhyuth / N16 $45.225^{\prime}$ E53²3.905' / 36 m wadi / 31.10.2018 / leg. L. Ábrahám, S. Ilniczky.

Distribution: It occurs in certain areas of the Middle East (coastal parts of Red and Dead Sea), across most of Arabia, also across sub-Saharan Africa. It is widespread in Oman, but much more common in Dhofar, than other regions of the country.

Remarks: It is the most widespread species of its genus, that ranges up to almost the Mediterranean Sea, also the only Anthene species found in Oman so far. The main host plants of this butterfly are Acacia (primarily A. tortilis in Oman) and Citrus species (Tshikolovets 2011). Like many other Lyceanidae species, A. amarah is associated with ants (MiLton 1990).

\section{Chilades trochylus (Freyer, 1845)}

Material examined: 3 exx. / OMAN, Region Al Batinah, N of Hubrah, N2329.005' E57 $49.988^{\prime} 194$ m, oasis 11.10.2009 leg. S. Ilniczky, S. J. Simonyi; 1 ex. OMAN, Gov. Dhofar, W of Al Mughsayl N16²51.243' E5343.149' 496 m, grassy hillside 13.10.2009 leg. S. Ilniczky, S. J. Simonyi; 2 exx. OMAN, Gov. Dhofar, W of Al Mughsayl N16²51.243' E53²43.149' 496 m, grassy hillside 06.07.2010 leg. S. Ilniczky, S. J. Simonyi; 1 ex. / OMAN, Gov. Dhofar / 3 km W of Rakhyuth / N16²45.225' E53²3.905' / 36 m wadi / 31.10.2018 / leg. L. Ábrahám, S. Ilniczky; 1 ex. / OMAN, Gov. Dhofar / 20 km W of Al Mughsayl / N16 $50.051^{\prime}$ E5 $53^{\circ} 42.552^{\prime}$ / 34 m seashore, dry rocky vegetation / 01.11.2018 / leg. L. Ábrahám, S. Ilniczky.

Taxonomic note: The species listed in the genus Freyeria Courvosier, 1920 in numerous earlier publications (e.g. LARSEN 1991, ACKERY et al. 1995), however, its status was re-assessed and it was moved into Chilades Moore, [1881] by LEEs et al. (2003).

Distribution: The Grass Jewel has a wide distribution, contrary to the fact that it is one of the smallest butterflies in the world: most of Africa, excluding north, the Middle East, through Arabia and India to Australia. In Europe, it reaches up north to the Greek islands, to mainland sourthern Greece and Southeastern Bulgaria (Burgas) (TsHikolovets 2011). It is widespread in Oman as well. 
Remarks: It prefers dry stony areas with sparse vegetation, also near cultivated fields. In Arabia, the host plants are Heliotropium and Indigofera, in Europe mostly Heliotropium hirsutissimum, Andrachne telephioides (TsHikolovets 2011).

Lampides boeticus (Linnaeus, 1767)

Material examined: 3 exx. / OMAN Gov. Dhofar/ Wadi Shaboun / N17³2.83'E54³8.78' / 386 m, dry forest / 01.05.2019 / leg. L. Ábrahám, S. Ilniczky, G. Körtési.

Distribution: It is distributed in the whole Old World, in the subtropical and tropical zones of Africa, Asia, Indo-China, Australia, also introduced to Hawaii (LoHMAN et al 2008). It has strong migratory tendencies, so it sometimes wanders up from the Mediterranean coast to the line of the southern coasts of the British Isles, to northern France, to Slovakia, and to the South Urals (Tshikolovets 2011). In Oman, it can be found almost everywhere.

Remarks: It is a rather common species in all parts of Oman. The host plants are different Fabaceae: Colutea, Crotalaria, Cytisus, Lathyrus in Europe (TshiKoloveTs 2011), mainly Sesbania, Taverniera and Medicago species in Arabia. The larvae also feed on cultivated pea species, occasionally causing agricultural damages (LARSEN \& LARSEN 1980).

Leptotes pirithous (Linnaeus, 1758)

Material examined: 8 exx. / OMAN Reg. Al Batinah South, N of Hubrah N13²9.005' E5749.988' 194 m, oasis, 11.10.2009 leg. S. Ilniczky, S. J. Simonyi; 2 exx. / OMAN, Gov. Dhofar / Wadi Shaboun / N17³2.83' E54³8.78' / 386 m dry forest / 01.05.2019 / leg. L. Ábrahám, S. Ilniczky, G. Körtési.

Distribution: A pan-African migratory species, which could be found in all kinds of habitat across the continent (LARSEN 2005). It is a rare migrant in most of Western and Central Europe, however, permanent and semi-permanent colonies could be found in the Mediterranean coast in Europe and Turkey, distributed across the Middle East, in the Arabian Peninsula to the Indian subcontinent (TsHIKOLOVETs 2011). It was first recorded in 1977 from the Dhofar Region (LARSEN 1977).

Remarks: It is a rather local species in Dhofar. The main hostplants are Leguminosae (Indigofera, Rynchosia, Vigna, Melilotus) (LARsen \& LARSEn 1980).

\section{Tarucus rosaceus (Austaut, 1885)}

Material examined: 12 exx. Oman, Jabal al Akhdar, Wadi Tanuf, N2304.564' E57 $29.736^{\prime} 768$ m, rocky gorge with sparse grove and shrubs, 29.04.2008 leg. S. Ilniczky, S. J. Simonyi; 2 exx. OMAN, Reg. Al Batinah South, N of Hubrah, N23²9.005' E57º49.988' 194 m, oasis 11.10.2009 leg. S. Ilniczky, S. J. Simonyi; 1 ex. / OMAN, Gov. Dhofar / $18 \mathrm{~km}$ from roadside between Sadah and Mirbat / N179.542' E5452.774' / 529 m dry rocky vegetation / 02.11.2018 / leg. L. Ábrahám, S. Ilniczky.

Distribution: Its range covers the northern coastal parts of Africa, also arid areas in the sub-Saharan part of the continent. The butterfly flies also in the Arabian Peninsula, through the Middle East to Pakistan. It can be found throughout Oman.

Remarks: The host plants are different Zizyphus species, such as Z. lotus, Z. spinachristi, Z. jujuba. Two further Taurucus species occurs also in Oman: T. balkanicus and T. theophrastus, all are closely related and very similar. T. rosaceus is a most common one, while T. theophrastus is known in a single population from Dhofar (LARSEN \& LARSEN 1980). 


\section{Zizeeria knysna (Trimen, 1862)}

Material examined: 1 ex. / OMAN, Gov. Dhofar / 7 km W of Mirbat / N1701.578' E54³9.322' / 31 m seashore, sand dunes / 03.11.2018 / leg. L. Ábrahám, S. Ilniczky.

Distribution: A pan-African species, which is present also in Northern Morocco and Northern Algeria, the Canary Islands, also the western part of the Arabian Peninsula. In Europe, it occurs much more sporadically in the southern half of the Iberian Peninsula and was also recorded on some Mediterranean islands (Sicily, Malta, Crete) (TsHikoLOVETS 2011). In Oman, this species occurs only in Dhofar. In the northern part of the country, an Oriental sister species, Z. karsandra (Moore, 1865) replaces Z. knysna. So far, the sympatric occurrence was not detected (LARSEN \& LARSEN 1980).

Remarks: The adults of this species are fond of lucerne-fields, also habitats with some kind of permanent water (wells, water pipes, drains, etc.). The larvae feed on various Medicago, Melilotus, Armeria and Leguminosae species (LARSEN \& LARSEN 1980).

\section{Zizula hylax (Fabricius, 1775)}

Material examined: 1 ex. / OMAN, Gov. Dhofar / 2 km E of Rakhyuth / N1644.968' E53²6.256' / 22 m seashore / 31.10.2018 / leg. L. Ábrahám, S. Ilniczky; 2 exx. / OMAN, Gov. Dhofar / 20 km W of Mughsayl / $\mathrm{N} 16^{\circ} 50.051^{\prime} \mathrm{E} 53^{\circ} 42.552^{\prime} / 34$ m seashore, dry rocky vegetation / 01.11.2018 / leg. L. Ábrahám, S. Ilniczky; 1 ex. / OMAN, Gov. Dhofar / Wadi Shaboun / N17³2.83’ E54³8.78' / 386 m dry forest / 01.05.2019 / leg. L. Ábrahám, S. Ilniczky, G. Körtési.

Distribution: It is distributed across sub-Saharan Africa, through Arabia and Asia to eastern and southern Australia. In the Arabian Peninsula, its distribution is limited to the Dhofar region in Oman. It was discovered recently on the island of Socotra in 2013 (FRIC \& Hula 2013).

Remarks: According to the literature, Z. hylax is a moderately common butterfly in Dhofar. Host plants include various members of the families Oxalidaceae and Acanthaceae (LARSEN \& LARSEN 1980).

\section{Azanus jesous (Guérin, 1847)}

Material examined: 1 ex. / OMAN, Gov. Dhofar, Jabal al Qara W of Al Mughsayl / N16 ${ }^{\circ} 51.243^{\prime}$ E53 ${ }^{\circ} 43.149^{\prime}$ 496 m, grassy hillside / 20.04.2008 / leg. S. Ilniczky, S. J. Simonyi; 2 exx. / OMAN Prov. Dhofar / Wadi Shaboun / N17³2.83’ E54³8.78' / 386 m dry forest / 01.05.2019 / leg. L. Ábrahám, S. Ilniczky, G. Körtési.

Distribution: It is widespread in the dry tropical African countries, occurring also in Morocco, Cyprus and in Middle East, through Arabia to India and Sri Lanka. The African Babul Blue can be found in all parts of Oman.

Remarks: A rather common species across the country. Two further closely related Azanus species also occur in Oman, but they are much scarcer and found only from Dhofar with certainty. All three Azanus are found in dry grassy habitats ranging from deserts, savannahs and thorn scrub, to clearings in the drier forests. The larval foodplants are Acacia (mostly A. tortilis and A. ehrenhergiana in Oman) and Entida species (LARSEN \& LARSEN 1980, TSHIKOLOVETS 2011). 


\section{Azanus ubaldus (Stoll, 1782)}

Material examined: 3 exx. / OMAN, Gov. Dhofar, Jabal al QaraW of Al Mughsayl / N16 $51.243^{\prime}$ E534․ $449^{\prime}$ 496 m, grassy hillside 06.07.2010 / leg. S. Ilniczky, S. J. Simonyi.

Distribution: It is distributed in the dry tropical parts of Africa, excluding North Africa, including the Eastern Canary Islands, the Middle East, Arabia to India and Sri Lanka. In Oman, so far only populations from Dhofar are known.

Remarks: Habitat use as in A. jesous. The host plants are probably various Acacia species, such as A. etbaica, A. tortilis and A. ehrenhergiana (LARSEN \& LARSEN 1980).

\section{Azanus moriqua (Wallengren,1857)}

Material examined: 1 ex. / OMAN, Gov. Dhofar, Jabal al Qara, W of Al Mughsayl / N16 ${ }^{\circ} 51.243^{\prime}$ E53⒋ $43.149^{\prime}$ 496 m, grassy hillside / 20.04.2008 / leg. S. Ilniczky, S. J. Simonyi.

Distribution: A. moriqua is widely distributed in the savannah zone of Africa, all the way to South Africa, and it occurs also in the Arabian Peninsula. It is widespread in Yemen, but in Oman, it is known only from Dhofar, by a handful of specimens (LARSEN 1982).

Remarks: It is a very scarce species in Oman. The host plants are rather likely Acacia species (LARSEN \& LARSEN 1980).

\section{Euchrysops osiris (Hopffer, 1855) (Figs. 28-29)}

Material examined: 4 exx. / OMAN, Gov. Dhofar / $20 \mathrm{~km} \mathrm{~W} \mathrm{of} \mathrm{Al} \mathrm{Mughsayl} \mathrm{/} \mathrm{N16} 50.051^{\prime}$ E53 ${ }^{\circ} 42.552^{\prime} / 34$ $\mathrm{m}$ seashore, dry, rocky vegetation / 01.11.2018 / leg. L. Ábrahám, S. Ilniczky.

Distribution: The Osiris Smokey Blue occurs in most of the African continent, south of the Sahara, including Madagascar. Its range reaches also the southern part of the Arabian Peninsula and here, the species is restricted to Dhofar in Oman.

Remarks: The host plants are Becium (B. filamentosum), Vigna and probably Ocimum species (LARSEN \& LARSEN 1980). The Oriental sister species of this butterfly, E. cnejus, was found in Northern Oman in 2019. Oman is the only country, where both of these Oriental and Afrotropical Euchrysops species are known to occur (FrIC et al. 2019).

\section{Theclinae Swainson, 1830 (1820) \\ Deudorix livia (Klug, 1834)}

Material examined: 11 exx. OMAN, Jabal al Akhdar, Balad Seet, N23⒒794' E57²3.476', bushy roadside above the village, 03.07.2010 leg. S. Ilniczky, S. J. Simonyi; 2 exx. / OMAN Reg, Al Dakhiliyah / Jabal Shams / N23ำ15.339' E57 $13.092^{\prime}$ / 2138 m rocky and bushy vegetation / 06.05.2019 / leg. L. Ábrahám, S. Ilniczky, G. Körtési.

Taxonomic note: In 2005, a subspecies, D. livia barnetti (Libert, 2005) was described from Jebel Akjdar Mountains, Northern Oman (LIBERT 2005) but the authors could not properly examine the subspecies status of the collected specimens, they are therefore listed collectively under D. livia.

Distribution: It is distributed in the northern arid zone of Africa, reaching South Algeria, Egypt, the Middle East, and most Arabia. The species was recorded also from Cyprus, and in mainland Greece in 2004 (MüLLER et al. 2005). In Oman, it is relatively 


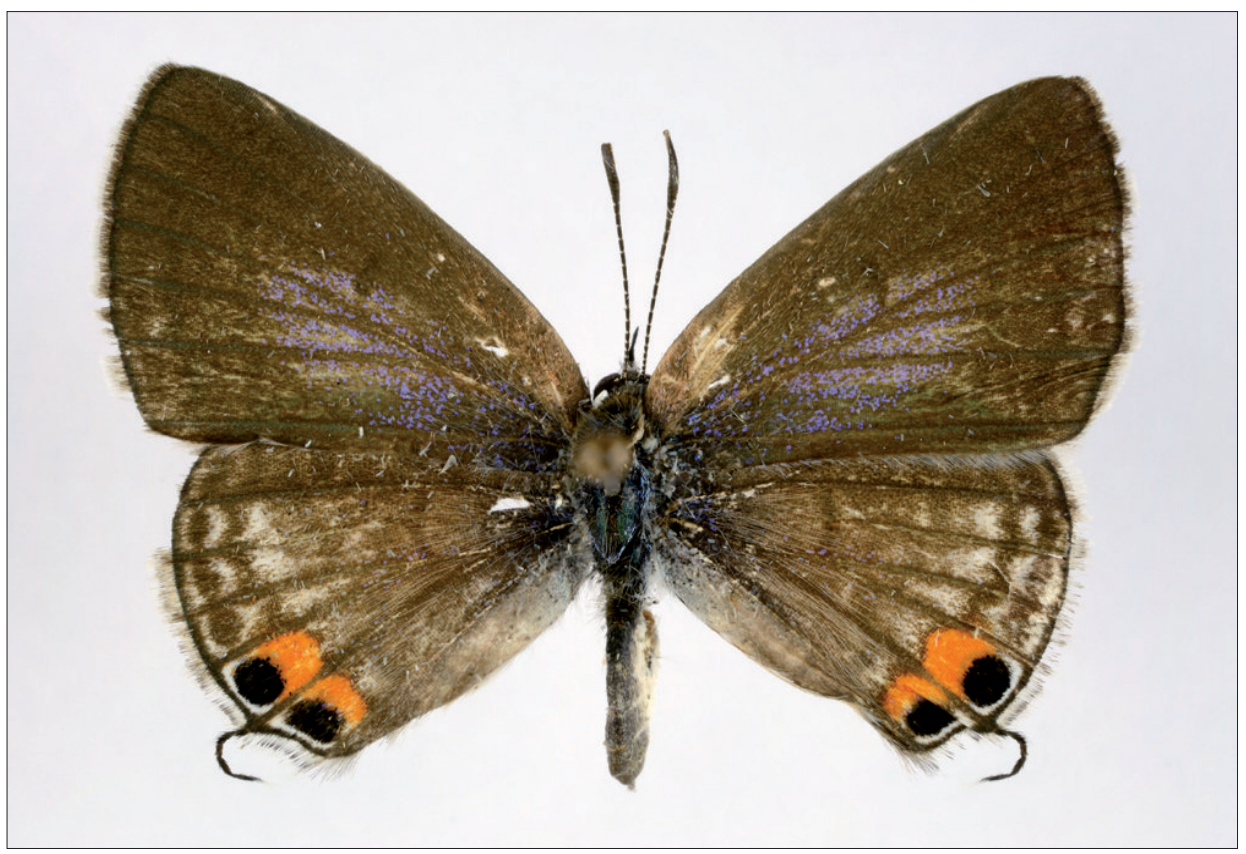

Fig. 28: Euchrysops osiris (Hopffer, 1855) female upper side

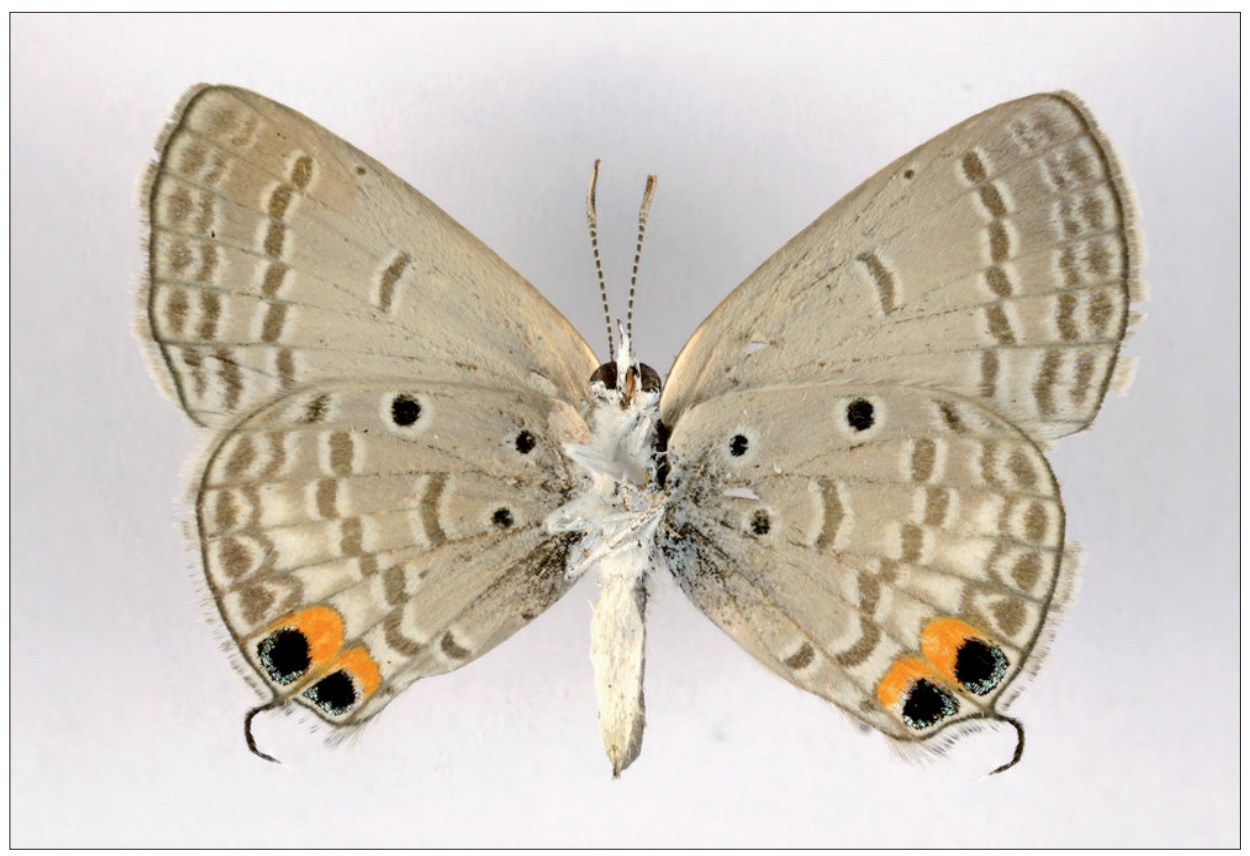

Fig. 29: Euchrysops osiris (Hopffer, 1855) female under side 


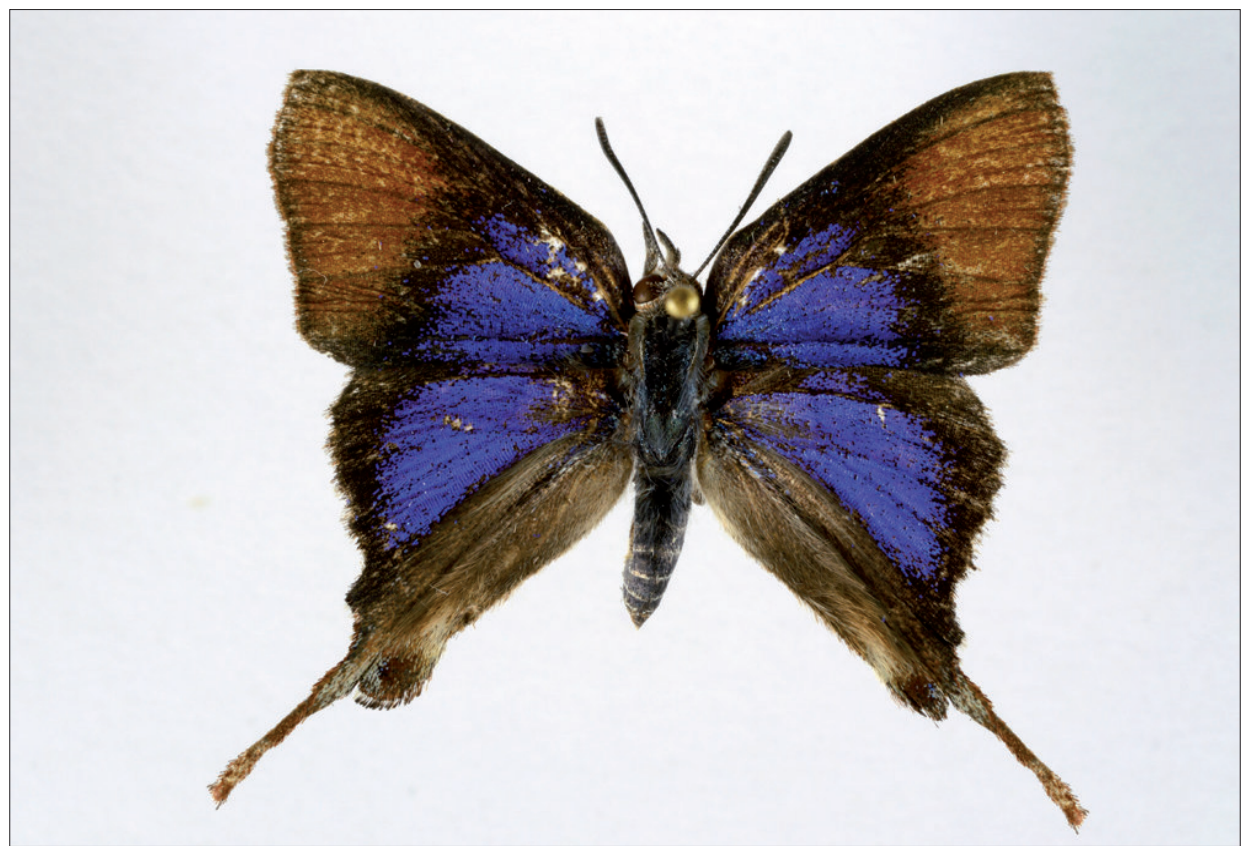

Fig. 30: Myrina silenus (Fabricius, 1775) male upper side

common in Dhofar, but a specimen was caught in Northern Oman too. The latter might belong to the above mentioned ssp. barnetti.

Remarks: It is mentioned as an occasional migrant in LARSEN (1991), this implies that the butterfly can be found in various countries and habitats. In its natural habitats, the main host plants are Acacia ehrenbergiana, A. farnesiana, although the larvae can feed on cultivated pomegranate (Punica granatum), loguat (Eriobortya japonica) and also dates (Phoenix dactylifera) (LARSEN \& LARSEN 1980).

\section{Myrina silenus (Fabricius, 1775) (Fig. 30)}

Material examined: 6 exx. / OMAN, Gov. Dhofar, Wadi Darbat, N1705.152' E54¹6.015' 198m, bushy pasture, 11.07.2010 leg. S. Ilniczky, S. J. Simonyi; 6 exx. / OMAN, Reg. Al Batinah South / Balad Seet / N23⒒794' E57²3.426 / 914 m oasis, spring / 06.05.2019 / leg. L. Ábrahám, S. Ilniczky, G. Körtési; 1 ex. OMAN Reg. Al Batinah South / Al Muladdah / N2342.134' E57³2.503' / 38 m / 07.05.2019 / leg. L. Ábrahám, S. Ilniczky, G. Körtési.

Distribution: The distribution of this unmistakable species consist of most of Africa, south of the Sahara, also the southern part of the Arabian Peninsula. In Oman, it occurs in Dhofar and Northern Oman as well.

Remarks: Hence the host plants of the species are common across Oman, M. silenus is a moderately frequent butterfly in the area. The larvae of the Common Fig-tree Blue develop on various Ficus species, such as F. salicifolia, F. carica, F. cordata, F. sur (LARSEN \& LARSEN 1980). 
Table 1. Distribution of the faunal elements of the Omani butterflies based on the recent survey

\begin{tabular}{|l|c|c|}
\hline Biogeographic region & Number of species & Percentage (\%) \\
\hline Afrotropic & 19 & 41 \\
\hline Paleartic & 15 & 33 \\
\hline Eremic & 8 & 17 \\
\hline Oriental & 3 & 7 \\
\hline Ubiquitous & 1 & 2 \\
\hline Altogether & $\mathbf{4 6}$ & $\mathbf{1 0 0 \%}$ \\
\hline
\end{tabular}

During the five insect collecting expeditions in Oman, altogether 485 specimens of 46 butterfly (Diurna) species were collected. The Omani butterfly fauna is considered to be rather species-poor; the first catalogue listed 72 species (LARSEN \& LARSEN 1980), since then only two furher species, Melanitis leda (Linnaeus, 1758) (CowAn \& CowAn 2019) and Euchrysops cnejus (Fabricius, 1798) (FrIC et al. 2019) were recorded as new for the country. So, 74 butterfly species are known from Oman so far, however, it further discoveries in the near future are not unlikely. All in all, $62 \%$ of the species of the Omani butterfly fauna was collected during the expeditions between 2008 and 2019.

The reason behind the relatively low species-diversity is clear; influenced by the arid climate and homogenous landscape, as the majority of the country is extremely dry, desert territory. Most part of the country is extremely dry, desert territory. Only two areas differ significantly, providing more diverse landscape and habitats, those consist of more varied habitats, thereby suitable for higher species diversity and density. These are the Northern Omani mountain regions (the Al Hajar Mountains), and the southwestern, more humid areas, known as the Dhofar Region (the Qara Mountains) where the majority of collecting also took place.

The biogeographic composition of the species collected corresponds that of LARSEN's (1980, 1984), confirming the dominance of the Afrotropical species in the butterfly fauna of Oman (41\%). Most of these species are confined to the southern part of Oman, especially the Dhofar Region. Relatively high proportion of the species is Palaearctic $(33 \%)$, the majority of them are restricted to the northern part of Oman. The desertdweller Eremic species (18\%) are distributed mostly in the dry, inner territories, and the eastern, Oriental species $(7 \%)$ also occur mostly in the northern mountainous areas.

The butterfly fauna of Oman is lacking endemic species. Although several subspecies are considered as endemic to the southwestern part of the Arabian Peninsula (eg. Teracolus eris contractus, Colotis daira daira), or to Oman (for instance Pyrrhiades anchises jucunda (also on the Island of Socotra)), or in a few occasions, restricted to Dhofar Region (eg. Charaxes hansali arabica and Charaxes varanes bertrami). These taxa are of high biogeographical interest and could be of conservation concern. Besides these, a few other species have to be mentioned, because these have a relatively small or sporadic global distribution (eg. Melitaea deserticola) or their populations are strongly isolated (eg. Hipparchia parisatis), though these local populations are still not considered to belong to a different subspecies. It would be an urgent task to re-assess the status of most Afrotropical taxa occurring on the Arabian Peninsula and Oman using molecular techniques for the proper conservation assessment of the fauna. 


\section{References}

ACkery, P. R., Smith, C. R. \& VAne-Wright, R. I. 1995: Carcasson's African Butterflies: An annotated Catalogue of the Papilionoidea and Hesperioidea of the Afrotropical Region. - British Museum (Natural History), London. 803 pp.

Aguiar, A. \& Wakeham-Dawson, A. 2001: On the status of Catopsilia florella (Fabricius, 1775) (Lepidoptera: Pieridae) in Madeira, Portugal nine moths after its arrival. - Entomologist's Gazette 52(2): 77-79.

BALl, L. 2013: An inventory of butterfly species from Wadi Sayq. - Pp. 85-91. in: BALL, L. 2013. Observations in the Empty Quarter and a rapid biodiversity assessment of Wadi Sayq, Dhofar. British Exploring Society, London.

Balletto, E. \& Larsen, T. B. 1985: On a small collection of butterflies from Yemen. - Monitore Zoologica Italiano Supplemento 20: 121-133.

Burgess, N. D., D'Amico Hales, J., Dinerstein, E., Itoua, I., Newman, K., Olson, D., Ricketts, T., SCHIPPER, J. \& Underwood, E. 2004: Terrestrial ecoregions of Africa and Madagascar: a conservation assessment. - Island Press, Washington D.C. xxiii 501 pp.

Chiba, H. 2009: A revision of the subfamily Coeliadinae (Lepidoptera: Hesperiidae). - Bulletin of the Kitakyushu Museum of Natural History and Human History, Serie A. 7: 1-102.

Cock, M. J. W. 2009: The biology of Pyrrhiades anchises jucunda (Butler) in northern Oman (Lepidoptera: Hesperiidae, Coeliadinae). - Tribulus 18: 37.

Cowan P. J. \& Cowan, E. M. 2019: A checklist of the butterflies of Dhofar, Oman and a record of the Common Evening Brown butterfly Melanitis leda (Linnaeus, 1758) in Dhofar. - Tribulus 27: 56-61.

Feulner, G. R. 2007: An unexpected resident butterfly of Northern Oman: the Arabian Grizzled Skipper Spialia mangana (Lepidoptera: Hesperiidae). - Tribulus 17: 99.

Fric, Z. F. \& Hula, V. 2013: Zizula hylax (Fabricius, 1775) new butterfly species for Socotra (Lepidoptera: Lycaenidae). - SHILAP Revista de Lepidopterología 41(164): 571-575.

Fric, F. Z. Besta, L., Hula, V., Vrba, P., Irungbam, M., Jatishwor Irungbam, J., Ignatev, N. \& Maresova, J. 2019: New record of the butterfly Euchrysops cnejus (Fabricius) from Oman, with notes about phylogeographic patterns of E. cnejus and E. osiris (Hopffer) (Lepidoptera: Lycaenidae). - Zoology in the Middle East 65(3): 236-244.

GHAZANFAR, S. A. 1992: Quantitative and biogeographic analysis of the flora of the Sultanate of Oman. Global Ecology and Biogeography Letters 2: 189-195.

Gillet, M. P. T. 1995: An updated and annotated list of butterflies recorded from the United Arab Emirates, the Musandam Penisula and Al-Buraimi. Al Mahdah regionof Sultanate Oman. - Tribulus 5(2): 16-20.

Gillet, M. P. T. \& NAsser, O. 2005: An aberrant Caper White butterfly, Anophaeis aurota, at Kuthwah, Oman (Lepidoptera: Pieridae). - Tribulus 15: 20.

GoRDON, I. J. 1987: Natural selection for rare and mimetic colour pattern combinations in wild populations of the diadem butterfly, Hypolimnas misippus L. - Biological Journal of the Linnean Society 31: 1-23.

Guerrero, K. A., Veloz, D., Boyce, S. L., Farrell, B. D. 2004: First New World Documentation of an Old World Citrus Pest, the Lime Swallowtail Papilio Demoleus (Lepidotera: Papilionidae), in the Dominican Republic (Hispaniola). - American Entomologist 50(4): 227-229.

HeAth, A. 1997: A review of African genera of the tribe Aphnaeini (Lepidoptera: Lycaenidae). - Metamorphosis Occasional Supplement No. 2: 1-60.

Heath, A., Newport, M.A. \& Hancock, D. 2002: The butterflies of Zambia. - African Butterfly Research Institute and The Lepidopterists' Society of Africa pp. i-xvii, 1-137.

KLUG, F. 1829-32: Symbolae Physicae seu icones et descriptiones insectorum, quae ex itenere per Africam borealem et Asiam occidentalem Friderici Guilhelmi Hemprich Et Christiani Godoferi Ehrenberg studio novae aut illustratae redierunt. Berlin.

KunTE, K. J. 2009: Female-limited mimetic polymorphism: a review of theories and a critique of sexual selection as balancing selection. Animal Behaviour. - http://dx.doi.org/https://doi.org/10.1016/j. anbehav.2009.08.013

LARSEN, T. B. 1977: The butterflies of eastern Oman and their zoogeographic composition. In: [unknown] (1977): The scientific results of the Oman flora and fauna survey 1975. - Journal of Oman Studies. Special Report No. 1: 179-208.

LARSEN, T. B. 1980: The Butterflies of Dhofar and their Zoogeographic Composition. In: [unknown] (1980): The Scientific Result of the Oman Flora and Fauna Survey 1977 (Dhofar). - Journal of Oman Studies, Special report No. 2: 153-186. 
LARSEN, T. B. 1982: The Butterflies of Yemen Arab Republic. With a Review of Species in the Charaxes violaGroup from Arabia and East Africa by A. H. B. Rydon. - Biologiske Skrifter SB 23(3): 1-87.

LARSEN, T. B. 1984a: The zoogeographical composition and distribution of the Arabian butterflies (Lepidoptera; Rhopalocera). - Journal of Biogeography 11(2): 119-158.

LARSEN, T. B. 1984b: Butterflies of Saudi Arabia and its neighbours. - Stacey International, London. 160 pp.

LARSEN, T. B. 1991: The Butterflies of Kenya and their Natural History. - Oxford University Press, Oxford. 490 pp. +22 colour plates.

Larsen, T. B. 2005: Butterflies of West Africa. - Apollo Books, Svendborg, Denmark. 595 pp. + 135 colour plates.

Larsen, T. B. \& Larsen, K. 1980: Butterflies of Oman. - Bartholomew Books, Edinburgh. pp. 1-80.

Larsen, T. B. \& NaKamura, I. 1983: The butterflies of East Jordan. Entomologist's Gazette. 34(3): 135-208.

Lees, D. C., Kremen, C. \& Raharitsimba, H. 2003: Classification, diversity and endemism of the butterflies (Papilionoidea and Hesperioidea): A revised species checklist. In: Goodman, S. M., Benstead, J. P. [Eds]. (2003). - The Natural History of Madagascar. University of Chicago Press, USA. 762-793.

LiBERT, M. 2005: Une nouvelle sous-espéce de Deudorix (Virachola) livia d’Oman (Lep. Lycaenidae). Bulletin de la Société entomologique de France 110 (3): 296-297.

Lohman, D. J., Duunijanti, P., Pierce, N., Meier, R. 2008: Phylogeography and generic diversity of a widespread Old World butterfly, Lampides boeticus (Lepidoptera: Lycaenidae). - BMC Evolutionary Biology 8(1): 301.

Mitton, S. J. 1990: A lycaenid butterfly (Anthene amarah Guerin) selects unseasonal young Acacia shoots for oviposition. - South-Africa Tydskr. Dierk 25(1): 84-85.

Morgun, D. V. \& Wiemers, M. 2012: First record of the Lime Swallowtail Papilio demoleus Linnaeus, 1758 (Lepidoptera, Papilionidae) in Europe. - The Journal of Research on the Lepidoptera 45: 85-89.

Müller, G. C., Kravchenko, V. D., Phillips, A., Shwarz-Tzachor, R. \& Benyamini, D. 2005: The first record of the Eremic Lycaenid Deudorix livia (Klug, 1834) in Europe. - Atalanta (Juli 2005) 36:(1/2): $109-112$.

NAsSER, O. 2005: A recent sighting of the Pomegranate Playboy butterfly, Deudorix livia, at Kuthwah, Oman (Lepidoptera: Lycaenidae). - Tribulus 15: 19.

Nazari, V., Larsen, T. B., Lees, D. C., Brattström, O., Bouyer, T., Van der Poel, G. \& Hebert, P. D. N. 2011: Phylogenetic systematics of Colotis and associated genera (Lepidoptera: Pieridae): evolutionary and taxonomic implications. - Journal of Zoological Systematics and Evolutionary Research. http://dx.doi. org/10.1111/j.1439-0469.2011.00

Polak, S. \& Verovnik, R. 1998: A contribution to the knowledge of the butterfly fauna of Dhofar- Sultanate of Oman (Lepidoptera: Rhopalocera). - Acta Entomologica Slovenica 6 (1): 55-65.

Polak, S. \& VerovniK, R. 2009: Second contribution to the knowledge of the butterfly fauna of the Sultanate of Oman (Lepidoptera: Rhopalocera). - Acta Entomologica Slovenica 17 (1): 37-44.

Sмiтн, D. A. S. 1973: Batesian mimicry between Danaus chrysippus and Hypolimnas misippus (Lepidoptera) in Tanzania. Nature, London 242 (5393): 129-131.

Smith, D. A. S., Lushai, G., Allen, J. A. 2005: A classification of Danaus butterflies (Lepidoptera: Nymphalidae) based upon data from morphology and DNA. - Zoological Journal of the Linnean Society 144: 191-212.

Tennent, J. 1996: The butterflies of Morocco, Algeria and Tunisia. - Gem Publishing Company, Wallingford. $217 \mathrm{pp}$.

Tshikolovets, V. V. 2011: Butterflies of Europe \& the Mediterranean area. - Tshikolovets Publications, Padubice, Czech Republic.

Verovnik, R., Beretta, S. \& Rowlings, M. 2018: Contribution to the knowledge of the spring butterfly fauna of the southern Anti-Atlas region, Morocco (Lepidoptera: Papilionoidea). - SHILAP Revista de Lepidopterología 46(181): 81-90.

Williams, J. G. 1973: A Field Guide to the Butterflies of Africa. - Collins, St James's Place, London

Williams, M. C. 2015: Classification of the Afrotropical butterflies to generic level. - Metamorphosis 26: 102-108.

Williams, M. C. 2019. Afrotropical butterflies and Skippers. A Digital Encyclopaedia. - http://www.metamorphosis.org.za/?p=articles\&s=atb (accessed: 04.04.2020). 
